Document downloaded from:

http://hdl.handle.net/10251/121255

This paper must be cited as:

Perez-Garcia, A.; Guardiola, AP.; Gómez-Martínez, F.; Guardiola Villora, AP. (2018).

Energy-saving potential of large housing stocks of listed buildings, case study: I'Eixample of Valencia. Sustainable Cities and Society. 42:59-81.

https://doi.org/10.1016/j.scs.2018.06.018

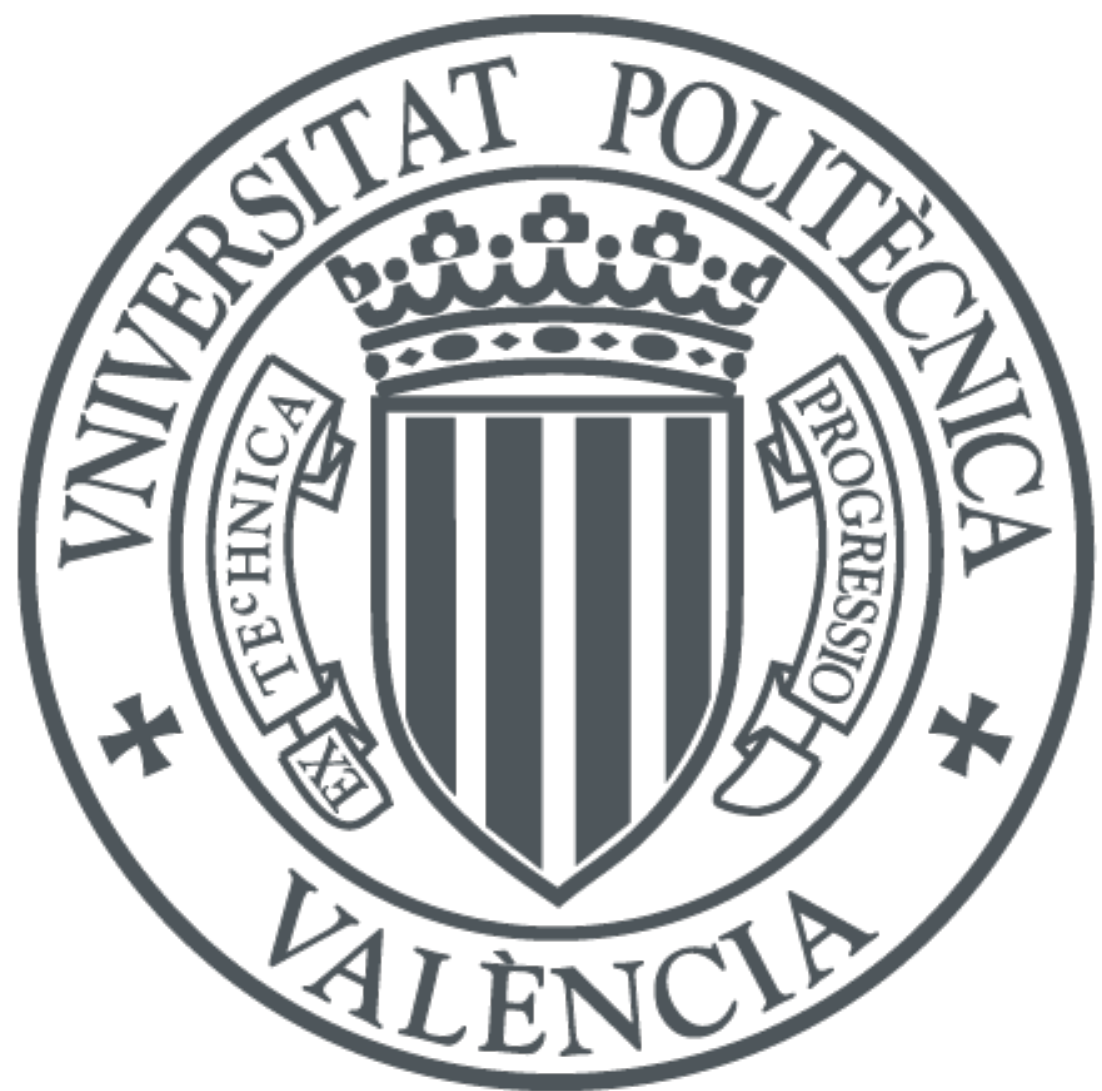

The final publication is available at

http://doi.org/10.1016/j.scs.2018.06.018

Copyright Elsevier

Additional Information 


\title{
Energy-saving potential of large housing stocks of listed buildings, case study: l'Eixample of Valencia
}

\author{
Agustin Perez-Garcia ${ }^{a, *}$, Agustin P. Guardiola $^{\mathrm{b}}$, Fernando Gómez-Martínez ${ }^{\mathrm{c}}$, Arianna \\ Guardiola-Vílora ${ }^{a}$ \\ a Universitat Politècnica de València. Valencia, Spain. \\ Departamento de Mecánica de los Medios Continuos y Teoría de Estructuras \\ b University of Manchester. Manchester, United Kingdom. \\ School of Physics and Astronomy \\ c Universitat Politècnica de València. Valencia, Spain. \\ Instituto de Ciencia y Tecnología del Hormigón
}

\begin{abstract}
A significant part of the European residential building stock is architectural heritage and is protected by law in different grades. Although these dwellings seldom fulfil the current eco-efficiency requirements, listed buildings are exempt from energy regulations requirements. This paper reviews the constructional characteristics common to 588 multi-storey listed buildings (circa 6000 dwellings) located in l'Eixample district in Valencia (Spain). The poor thermal performance of these buildings proven by this study reveal a significant potential for saving energy and reducing $\mathrm{CO}_{2}$ emissions, particularly when considering the current requirements fixed by the current Spanish building code. Retrofitting measures, intended to improve the thermal behaviour of the envelope of these buildings while being respectful with their listed nature, are proposed for further analysis.
\end{abstract}

Keywords: Listed buildings; Architectural heritage; Thermal performance; Retrofitting; Residential buildings; Building envelope

\begin{abstract}
Some contents of this paper are based on a preliminary study presented as a short communication to the International Conference on Vernacular Heritage, Sustainability and Earthen Architecture. VerSus2014. Valencia, Spain, in September 11-13, 2014. That contribution has been later selected to be published in "Vernacular Architecture: Towards a Sustainable Future"; Mileto, Vegas, Garcia Soriano \& Cristini (Eds), Taylor \& Francis Group, 2015, London, ISBN 978-1-138-02682-7. Authors and publisher consent the inclusion of that material into this paper.
\end{abstract}

\footnotetext{
* Corresponding author. Tel.: +34666327217; fax: +34963879679. E-mail address: aperezg@ mes.upv.es Universitat Politècnica de València. Camino de Vera s/n, 46022 Valencia, Spain
} 


\section{Energy-saving potential of large housing stocks of listed 2 buildings, case study: l'Eixample of Valencia}

3

4

5

6

7

8

9

10

11

12

13

14

15

16

17

18

19

20

21

22

23

24

25

26

27

28

29

30

31 (26

\section{ABSTRACT}

A significant part of the European residential building stock is architectural heritage and is protected by law in different grades. Although these dwellings seldom fulfil the current eco-efficiency requirements, listed buildings are exempt from energy regulations requirements. This paper reviews the constructional characteristics common to 588 multi-storey listed buildings (circa 6000 dwellings) located in l'Eixample district in Valencia (Spain). The poor thermal performance of these buildings proven by this study reveal a significant potential for saving energy and reducing $\mathrm{CO}_{2}$ emissions, particularly when considering the current requirements fixed by the current Spanish building code. Retrofitting measures, intended to improve the thermal behaviour of the envelope of these buildings while being respectful with their listed nature, are proposed for further analysis.

Keywords: Listed buildings; Architectural heritage; Thermal performance; Retrofitting; Residential buildings; Building envelope 


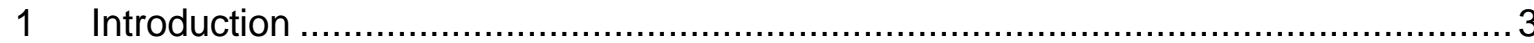

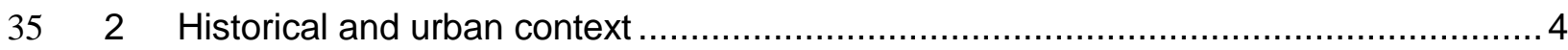

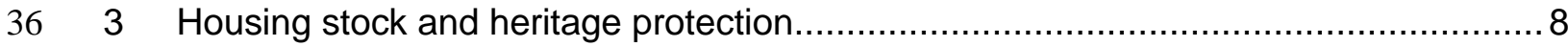

374 Construction details and thermal behaviour of the analysed built heritage............... 12

$38 \quad 4.1 \quad$ Provisions of the current Spanish Building Code ........................................ 13

$39 \quad 4.2$ Compared analysis of construction characteristics ......................................... 15

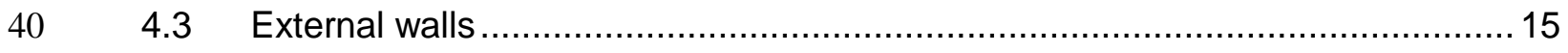

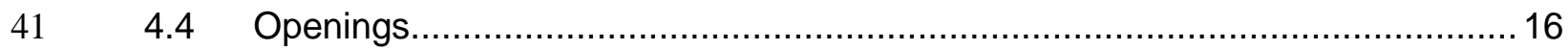

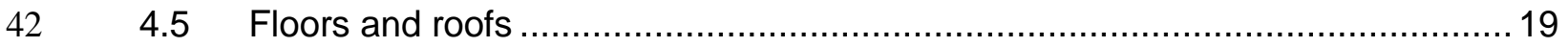

$43 \quad 4.6$ Summary of results and energy-saving potential of the building envelope ......... 23

445 Space heating/cooling systems and domestic hot water production .......................24

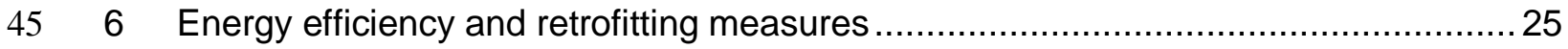

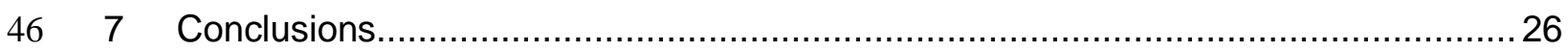

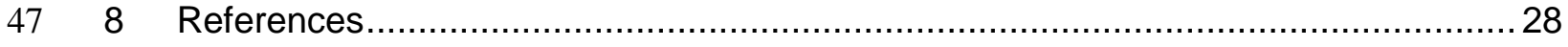




\section{Introduction}

Buildings, along their long-life cycle, not only consume large amounts of energy but also contribute substantially to greenhouse emissions. The energy-saving potential of residential buildings has been broadly verified by both means of European scale analyses (International Energy Agency, Guertler, \& Smith, 2006; Lechtenböhmer \& Schüring, 2010; Nemry et al., 2008, 2010) and also reviewing and detailing this potential in many countries across Europe, from South (Greece (Balaras et al., 2007; Droutsa, Kontoyiannidis, Dascalaki, \& Balaras, 2016), Italy (Mazzarella, 2014), Spain (Ministerio de Industria Energía y Turismo, 2011; WWF, 2010)) to North (Denmark (Morelli et al., 2012; Tommerup \& Svendsen, 2006), Sweden (Liu, Moshfegh, Akander, \& Cehlin, 2014), Finland (Alev et al., 2014)). Accordingly, the implementation of the climate strategy of the European Union for 2020 (European Commission, n.d.-a) and 2030 (European Commission, n.d.-b) requires a substantial improvement of the eco-efficiency of Europe's residential building stock. As a result, the efficient thermal behaviour of residential buildings is a relevant issue in regard to the sustainability of cities (Monzón \& López-Mesa, 2018).

Many cities have large historical city centres and many buildings included in such areas would presumably require extensive retrofitting to fulfil the current comfort and energy-efficient requirements. However, listed buildings are usually out of the scope of this potential improvement because they are part of the architectural heritage and, very often, protection provisions prevent many usual retrofitting works. While this exceptional consideration could be acceptable for singular pieces of architecture it should not be automatically claimed for large housing stocks of listed buildings. The energy-saving potential of this part of the architectural heritage is sometimes large enough to be taken into consideration and specific studies of compatible retrofitting measures are advisable.

This case study is focused in the city of Valencia (Spain) and will show the energy-saving potential associated to the retrofitting of a large dwelling stock located in listed buildings built from 1887 to 1940 in this city. 
2 Historical and urban context

The city of Valencia is located on the Mediterranean coast of the Iberian Peninsula (Fig. 1) and was created as a Roman settlement, named Valentia, in 138 BC. Later on, the city was taken by the Visigoths, extended by the Arabs and finally conquered by the Christians along the thirteenth century. During this time the growth of the town was permanently constrained by the city walls: first the Islamic ramparts and later the Christian fortifications. Nevertheless, this ancient part of the city, called Ciutat Vella (Fig. 2), is one of the largest historical city centre in Spain (approximately 170 ha).

84

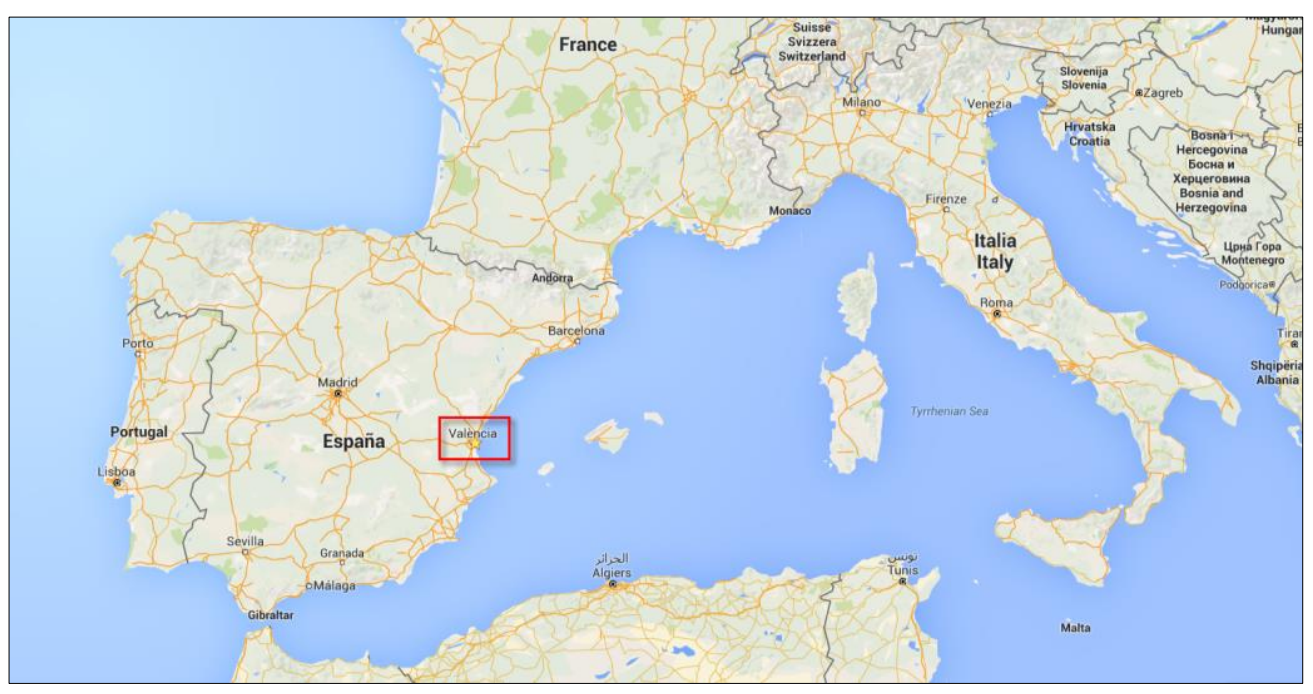

Fig. 1 Location of the of Valencia in Spain (Google Maps, n.d.) 


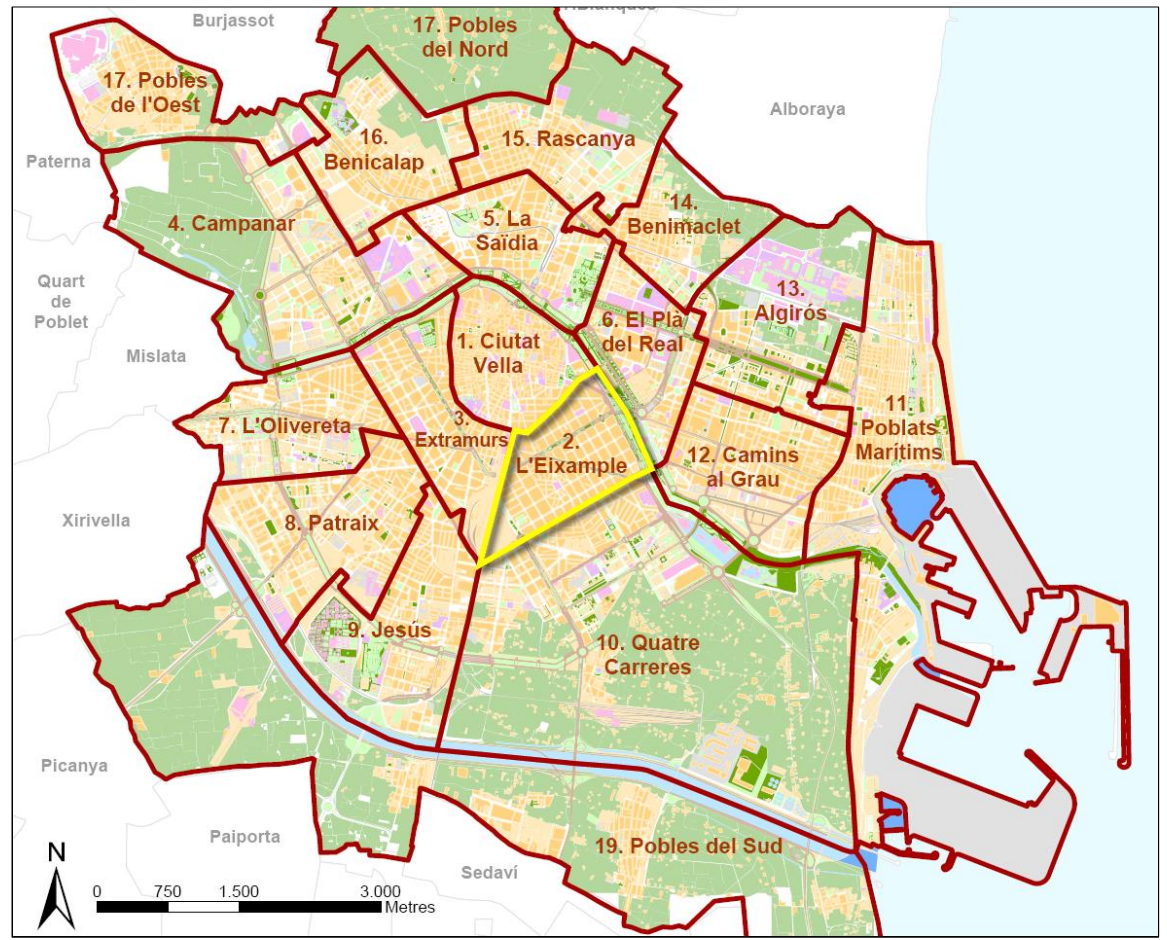

Fig. 2 City Districts, Old Town and the Eixample (area of study) (City Council of Valencia, n.d.)

At the end of the $19^{\text {th }}$ century Valencia had 100,000 inhabitants and experienced an important wealth period that required the expansion of the city. The city walls were demolished in 1865 and the city began to extend towards the South-East. The opening of new avenues stimulated the rapid urbanization of this part of the city. This new neighbourhood, known as l'Eixample, was developed following the paradigm of modern-planned city proposed by Ildefonso Cerdá (Soria y Puig, 1995) to design the city of Barcelona in the $19^{\text {th }}$ century. Consequently, l'Eixample grew following a regular morphology pattern based on rectangular urban blocks including a large common backyard (Fig. 3a). Blocks are separated by streets and chamfered at the corners. The distance between opposite facades along the street is $16 \mathrm{~m}$ while at the chamfers is $40 \mathrm{~m}$ (Fig. 3b). This area was urbanised in two phases (Fig. 4). The first phase, named Pla del Remei, was developed according to a planning project approved in 1887 . The second phase, named Ensanche de Mora, was urbanised following a project, sanctioned in 1912, that included the old municipality of Russafa. 


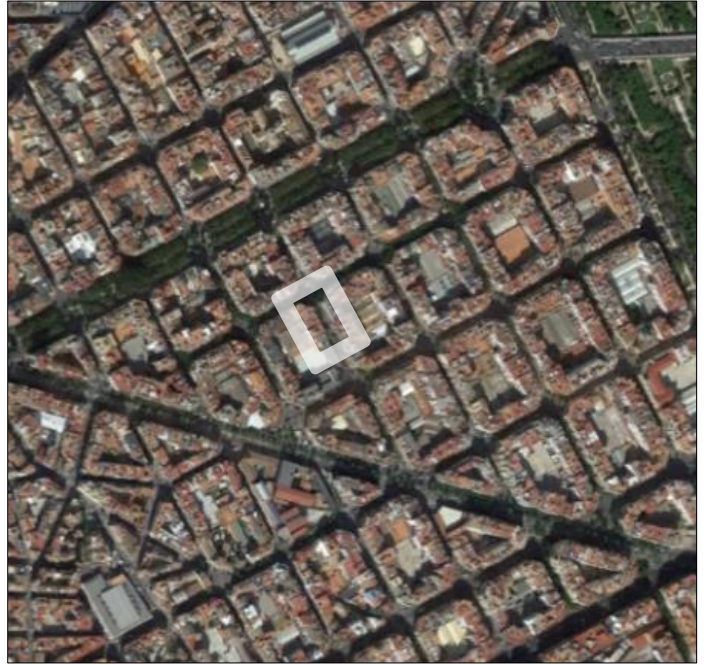

a. Blocks arranged following the characteristic urban
pattern at the Eixample

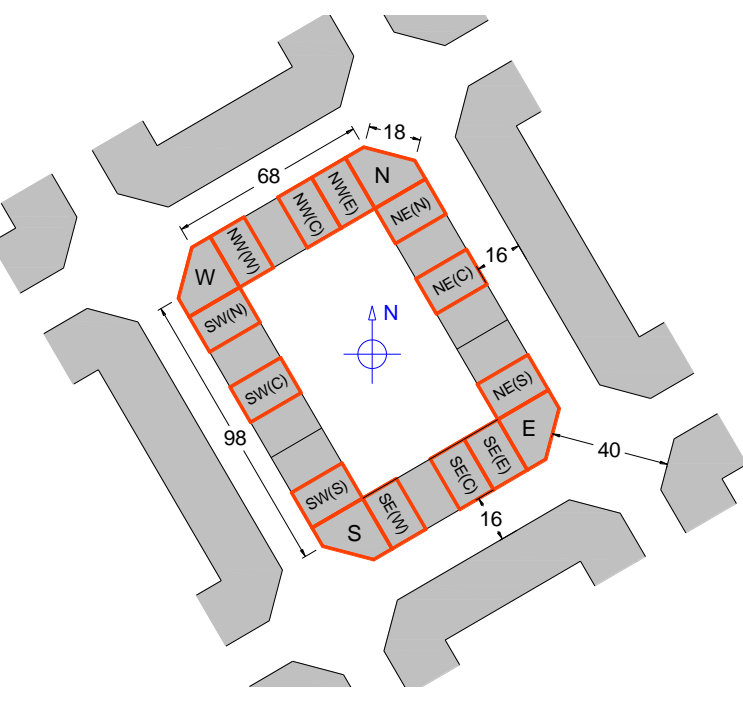

b. Location, orientation and reference code of the 16 buildings 16 assessed on each block

Fig. 3 Urban fabric and buildings' orientation

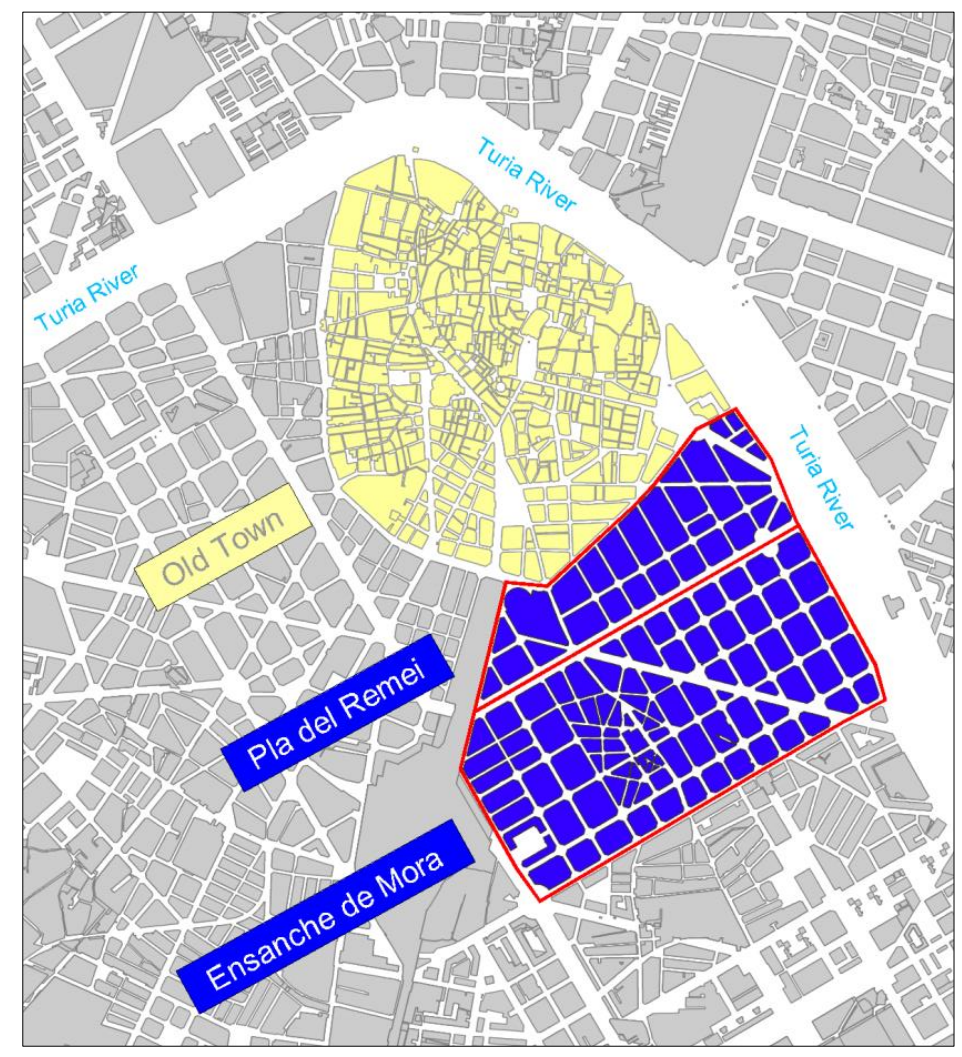

Fig. 4 Old Town and the Eixample district (Pla del Remei and Ensanche de Mora)

In this district there are over 2.400 multi-storey buildings. Most of them are dwellings and, because of their architectural value as the finest Modernist or Eclectic style buildings of the city (Fig. 5), circa 27\% are listed (Fig. 6). These buildings regularly have six floors above ground 
118 (around $22 \mathrm{~m}$ height) and no basement (Fig. 7). Typically, the ground and the first floor are

119 shops and offices while the rest of the building has residential use.
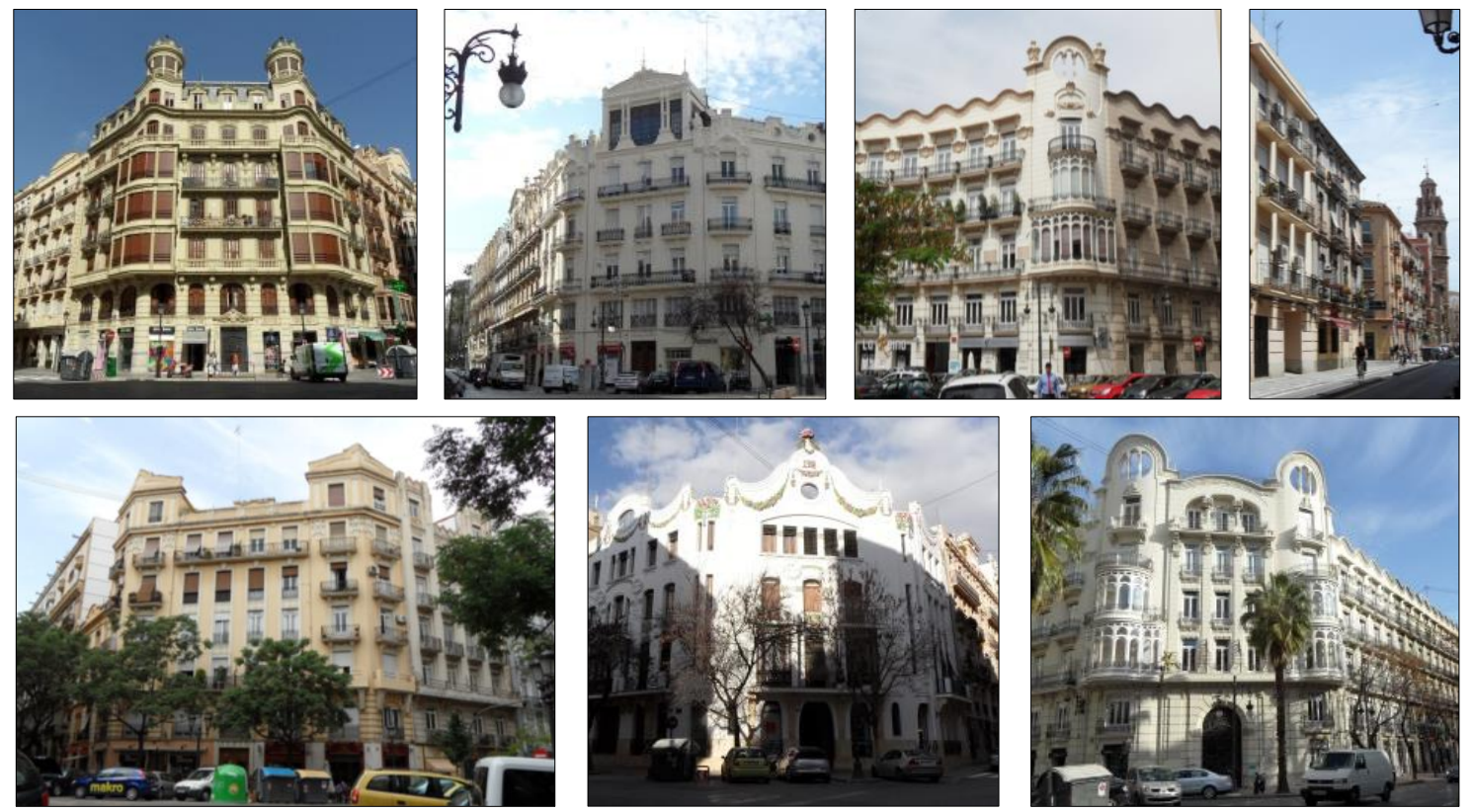

Fig. 5 Some Modernist listed buildings at the Eixample of Valencia

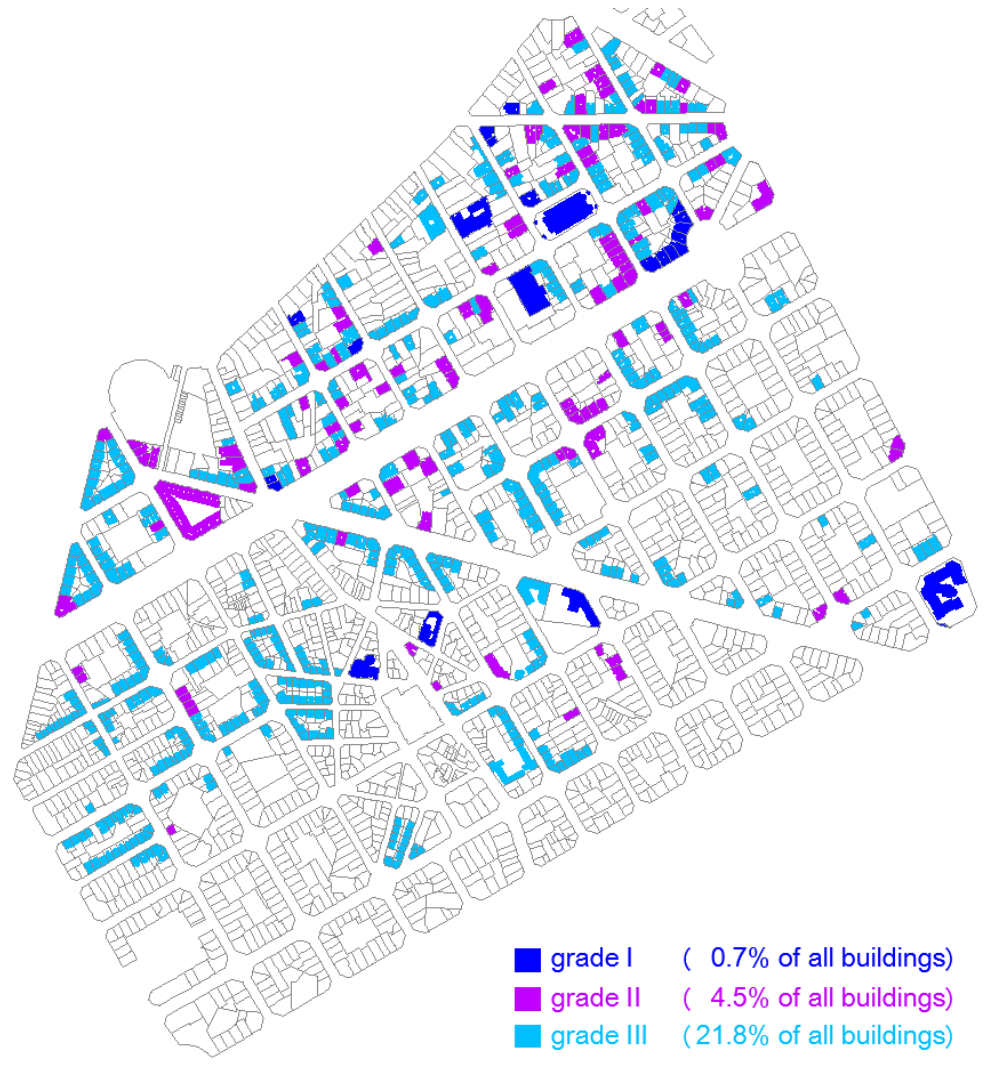

Fig. 6 Location of the 653 listed buildings at the Eixample and their protection grades (data source (City Council of Valencia, 2005) (City Council of Valencia, 2007)) 
128

129

130

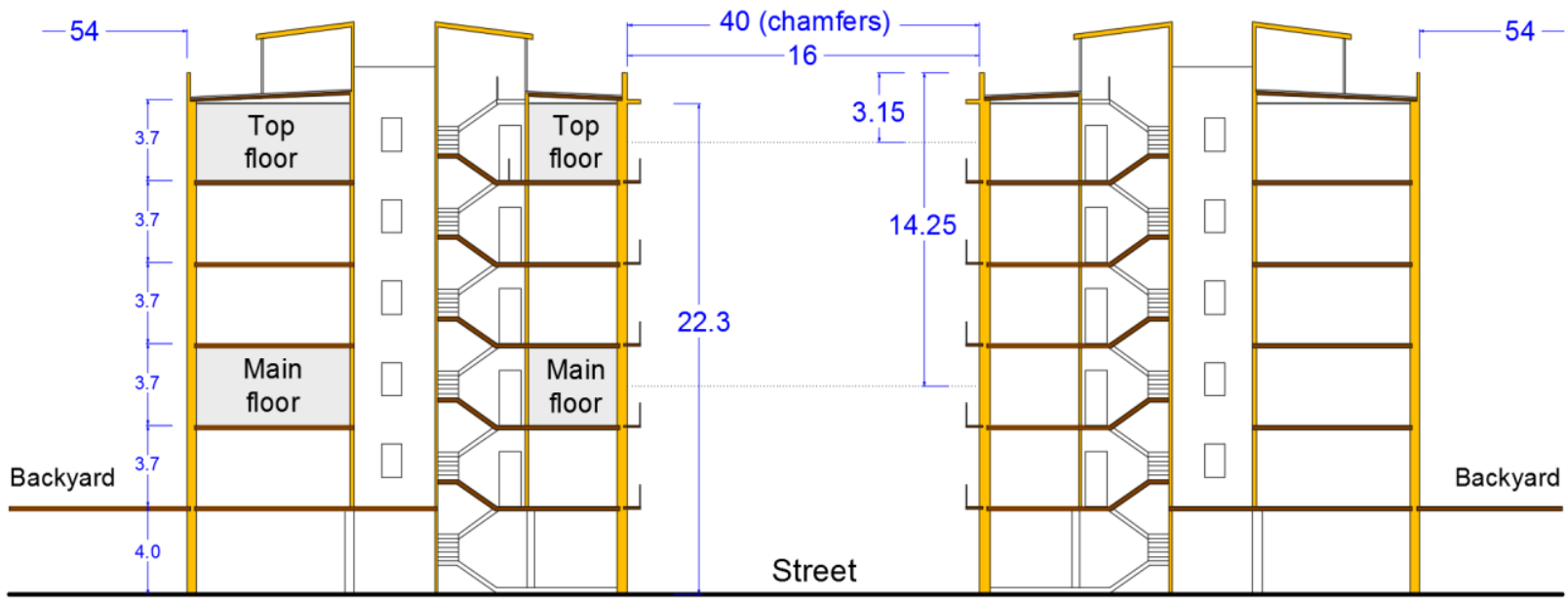

Fig. 7 Cross section of buildings (with street and chamfers breadth)

The purpose of this study has been to review the construction details of the buildings erected in Valencia during the abovementioned urban expansion in order to assess their thermal behaviour and propose appropriate retrofitting measures to improve the energy performance of this architectural heritage.

\section{Housing stock and heritage protection}

The identifiable character of the architectural heritage of I'Eixample district was dramatically damaged from 1960 to 1970 . During this period of rapid economic growth, new buildings replaced the existing ones causing a significant change of the urban scene in both areas of l'Eixample.

Trying to stop the decline of the urban fabric and the architectural heritage of the city, the historical city centre of Valencia was declared conservation area in 1978. Since then the local authorities have produced several Conservation Area Management Plans in order to protect not only the antique town but also many buildings in l'Eixample district.

The Pla del Remei area was declared Heritage of Cultural Interest in 1993. This statement required the design of a Special Protection Plan (SPP) to preserve the urban structure and build- 
146 ing stock of the area. This Plan, SPP-1 (City Council of Valencia, 2005), was approved in 2005

147 intending to safeguard an area of 45.5 ha that included 571 buildings. Two years later a second 148 Plan was approved for the Ensanche de Mora, SPP-2 (City Council of Valencia, 2007), aiming 149 to protect an area of 102.8 ha that encompassed 1836 buildings. Both plans established a set of 150 rules aimed to restore the original architectural and constructional consistency of this district by 151 means of careful retrofitting.

152 According to the SPP-1 and SPP-2, the protection grades and admitted retrofitting works at the 153 Eixample are defined as follows:

154 - "Grade I. Buildings of exceptional interest, sometimes considered to be of national or international 155 importance. They are buildings whose architectural value requires consideration of the structural unit 156 as a whole. They must be kept unchanged. Therefore, listing covers the whole building, including all the elements that define the architectural composition: facades, roofing, entrance-hall design, stairs position, etc., including the internal distribution and finishes. Intervention must be consistent with the

- "Grade III. Buildings of environmental value because they constitute the urban scene where Grade I and Grade II buildings are located. $82 \%$ of the Eixample listed buildings belong to this type, being the most likely grade of listing for residential building. In addition to the restoration and conservation works, retrofitting and substantial changes are allowed provided that the architectural parts explicitly indicated in each individual dossier are preserved." 
174 Following this grade description, 653 buildings were listed (Fig. 6) and classified into five differ-

175 ent types (Fig. 8). Each type was characterised by: similarity in plan and facade composition;

176 use of the same construction materials and homogeneity of construction crafts. The differences

177 between them are founded in the location of the stairs and the addition, or lack, of inner patios

178 for ventilation purposes. This composition is directly related to the building's depth and the size of the remaining internal backyard of each urban block.

Buildings of type $\mathbf{A}$ follow the mansion dwelling model used in the last third of the $19^{\text {th }}$ century. It was widely tested and validated by architects and craftsmen within the historic city centre of Valencia. These houses were owned by wealthy families that occupied the main storey, with the rest of levels usually being available for renting. This type of building usually has four or five floors and a big entrance with a large wooden door leading to the inner backyard or garden.

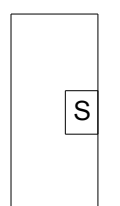

$\mathrm{B}_{2}$

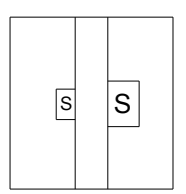

A

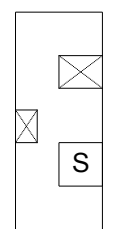

$\mathrm{C}_{2}$

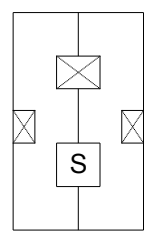

$\mathrm{C}_{1}$

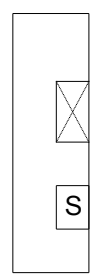

$\mathrm{D}_{2}$

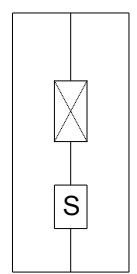

$D_{1}$

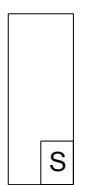

$\mathrm{E}_{2}$

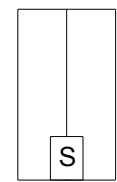

$E_{1}$

Fig. 8 Plan sketch of residential listed building types at the Eixample (data source (Alonso \& Almazán, 2012))

Buildings of type $\mathbf{B}$ are an evolution of type A. Changes were introduced to meet the requirements of the rental housing market. Plan and cross section composition were changed but the hierarchy levels of type A were kept. Type $\mathbf{C}$ evolved from type B merely increasing the total floor area. The building depth was enlarged by adding a bay and the height increased to six/seven floors. These changes required the introduction of ventilation and lighting patios that 
had to be designed according to building regulations. This type is followed by the first and more remarkable examples of Rationalism style in Valencia. A new structural system for floors was adopted (using rolled steel) and most importantly, a new language for the composition of the facade.

Type $\mathbf{D}$ buildings are the last step in the transformation of buildings type B and $\mathrm{C}$. The total floor area was substantially increased and the residential building requirements rationalised. The number of storeys increases to nine floors and the building depth reaches eight bays. Illumination and ventilation is guaranteed by the existence of one large inner backyard. These buildings were the first to be built using reinforced concrete structural rigid frames. Finally, buildings of type $\mathbf{E}$ are small and the stairs are placed in the first bay. They have four or five floors and two dwellings in each storey. These buildings were intended to be rented by low-middle class families. This type constitutes a unique variant in this district and is found only in the Russafa quarter. With a neat and modest exterior ornamentation, it is the homogeneous and well finished facade what constitutes the particular character that creates a valuable urban scenario.

Of all listed buildings in the Eixample, $90 \%$ were classified as type $\mathbf{B}$ or $\mathbf{C}$ (Table 1).

\begin{tabular}{|c|c|c|c|c|c|c|}
\hline \multirow{2}{*}{$\begin{array}{c}\text { Special } \\
\text { Protection } \\
\text { Plan }\end{array}$} & \multirow{2}{*}{$\begin{array}{l}\text { Buildings } \\
\text { included }\end{array}$} & \multicolumn{5}{|c|}{ Listed buildings } \\
\hline & & \multicolumn{2}{|c|}{ Amount and \% } & \multicolumn{3}{|c|}{ Type of listed building } \\
\hline \multirow{3}{*}{$\begin{array}{l}\text { SPP-1 } \\
\text { Pla del } \\
\text { Remei }\end{array}$} & \multirow{3}{*}{571} & \multirow{3}{*}{286} & \multirow{3}{*}{$50 \%$} & $B$ & 38 & $13 \%$ \\
\hline & & & & C & 203 & $71 \%$ \\
\hline & & & & & & \\
\hline \multirow{3}{*}{$\begin{array}{c}\text { SPP-2 } \\
\text { Ensanche } \\
\text { de Mora }\end{array}$} & \multirow{3}{*}{1836} & \multirow{3}{*}{367} & \multirow{3}{*}{$20 \%$} & & & \\
\hline & & & & $B$ & 198 & $54 \%$ \\
\hline & & & & $\mathrm{C}$ & 149 & $41 \%$ \\
\hline Total & 2407 & 653 & $27 \%$ & B or $C$ & 588 & $90 \%$ \\
\hline
\end{tabular}

Table 1 Type of listed buildings included in SPP-1 and SPP-2 (data source (Alonso \& Almazán, 2012))

According to the City Council, only $6 \%$ of the residential stock in l'Eixample area has been built in the last 25 years and nearly 43\% was built before 1940 (Fig. 9). Moreover, 78\% of the listed 
216 buildings included in SPP-1 and 94\% of those included in SPP-2 were built from 1887 to 1940

217 (Table 2). All these dwellings were built according to the early twentieth century standards of

218 habitability, comfort, and thermal insulation, and they presumably do not fulfil the current build-

219 ing's energy efficiency requirements.

220

221

4 Construction details and thermal behaviour of the analysed built heritage

228 In this section, the main constructional characteristics and the thermal behaviour of the enve-

229 lope of the most frequent types of listed buildings in l'Eixample of Valencia (types B or C) are
Fig. 9 Age of buildings at the Eixample (data source (City Council of Valencia, 2013))

\begin{tabular}{|c|c|c|c|c|c|c|c|}
\hline \multirow{2}{*}{$\begin{array}{c}\text { Special } \\
\text { Protection } \\
\text { Plan } \\
\end{array}$} & \multirow{2}{*}{$\begin{array}{l}\text { Buildings } \\
\text { included }\end{array}$} & \multicolumn{6}{|c|}{ Listed buildings } \\
\hline & & \multicolumn{2}{|c|}{ Amount and \% } & \multicolumn{4}{|c|}{ Period of construction } \\
\hline \multirow{4}{*}{$\begin{array}{l}\text { SPP-1 } \\
\text { Pla del } \\
\text { Remei }\end{array}$} & \multirow{4}{*}{571} & \multirow{4}{*}{286} & \multirow{4}{*}{$50 \%$} & $1887-1900$ & 26 & $9 \%$ & \multirow{3}{*}{$78 \%$} \\
\hline & & & & $1901-1920$ & 80 & $28 \%$ & \\
\hline & & & & 1921-1940 & 117 & $41 \%$ & \\
\hline & & & & 1941-1980 & 63 & $22 \%$ & \\
\hline \multirow{4}{*}{$\begin{array}{c}\text { SPP-2 } \\
\text { Ensanche } \\
\text { de Mora }\end{array}$} & \multirow{4}{*}{1836} & \multirow{4}{*}{367} & \multirow{4}{*}{$20 \%$} & $1887-1900$ & 23 & $6 \%$ & \multirow{3}{*}{$94 \%$} \\
\hline & & & & 1901-1920 & 122 & $33 \%$ & \\
\hline & & & & $1921-1940$ & 199 & $54 \%$ & \\
\hline & & & & 1941-1980 & 23 & $6 \%$ & \\
\hline Total & 2407 & 653 & $27 \%$ & 1887-1940 & 567 & $87 \%$ & \\
\hline
\end{tabular}

Table 2 Age of listed buildings included in SPP-1 and SPP-2 
analysed in order to appraise the energy-saving potential of this large housing stock (588 build-

231 ings containing circa 6000 dwellings).

\subsection{Provisions of the current Spanish Building Code}

The current Spanish Building Code (CTE-HE) (Ministerio de Fomento. Gobierno de España, 2013) defines different climate zones and fixes the maximum allowed transmittances of each part of the building envelope for each climate zone (Fig. 10). The city of Valencia has a mild Mediterranean climate and it is located in climate zone B.

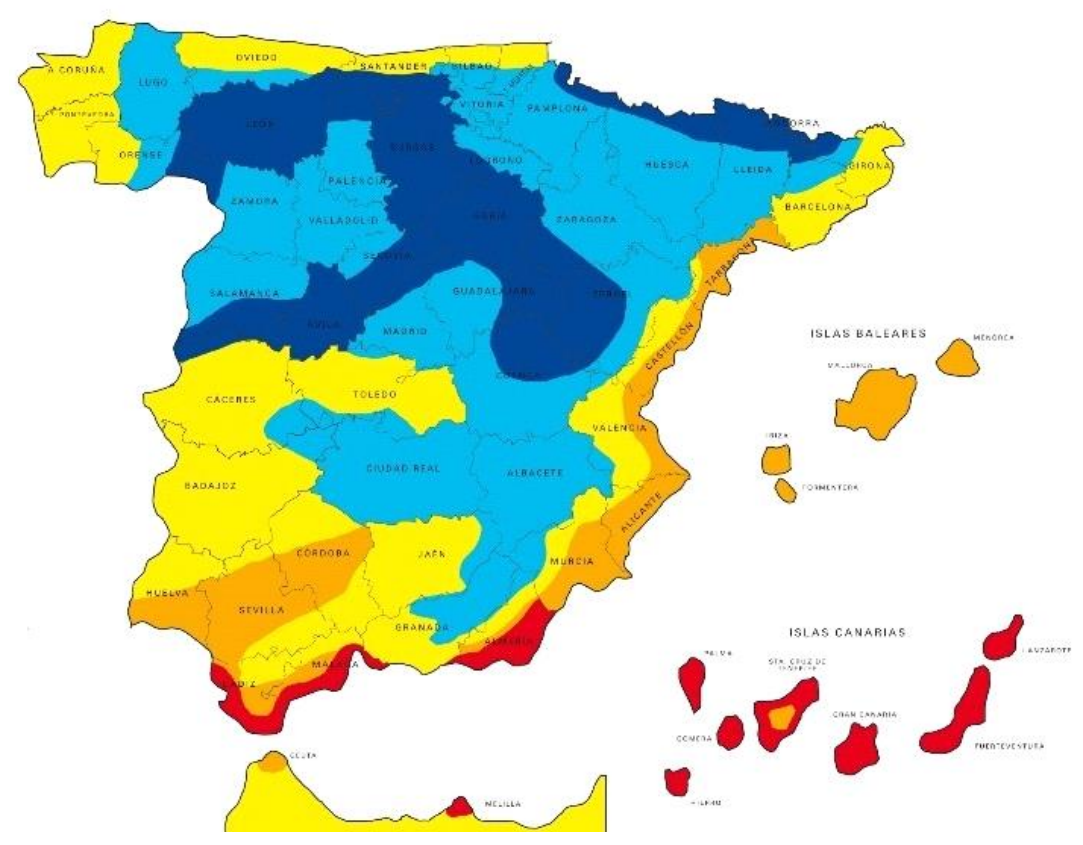

\begin{tabular}{|l|c|c|c|c|c|}
\cline { 2 - 6 } \multicolumn{1}{c|}{} & \multicolumn{5}{c|}{ Maximum allowed $\mathrm{U}_{\text {value }}\left[\mathrm{W} / \mathrm{m}^{2} \cdot \mathrm{K}\right]$} \\
\hline Spanish climate zones & $\mathrm{A}$ & $\mathbf{B}$ & $\mathrm{C}$ & $\mathrm{D}$ & $\mathrm{E}$ \\
\hline External walls & 1.25 & $\mathbf{1 . 0 0}$ & 0.75 & 0.60 & 0.55 \\
\hline Party walls & 1.25 & $\mathbf{1 . 1 0}$ & 0.95 & 0.85 & 0.70 \\
\hline Partitions (same use) & 1.40 & $\mathbf{1 . 2 0}$ & 1.20 & 1.20 & 1.00 \\
\hline Roofs and Floors & 0.80 & $\mathbf{0 . 6 5}$ & 0.50 & 0.40 & 0.35 \\
\hline Openings & 5.70 & $\mathbf{4 . 2 0}$ & 3.10 & 2.70 & 2.50 \\
\hline
\end{tabular}

Fig. 10 Maximum allowed transmittance for each Spanish climate zone (Ministerio de Fomento. Gobierno de España, 2013)

Additionally, the CTE-HE code recommends lower reference $U_{\text {values }}$ in order to achieve reasonable thermal efficiencies (Fig. 11). The recommended transmittance threshold for external walls is $0.82 \mathrm{~W} / \mathrm{m}^{2} \mathrm{~K}$ while the limit value proposed for roofs is $0.45 \mathrm{~W} / \mathrm{m}^{2} \mathrm{~K}$. For facades where the 
opening ratio ranges from $51 \%$ to $60 \%$ of the total wall area, the $\bigcup_{\text {value }}$ recommended limits are:

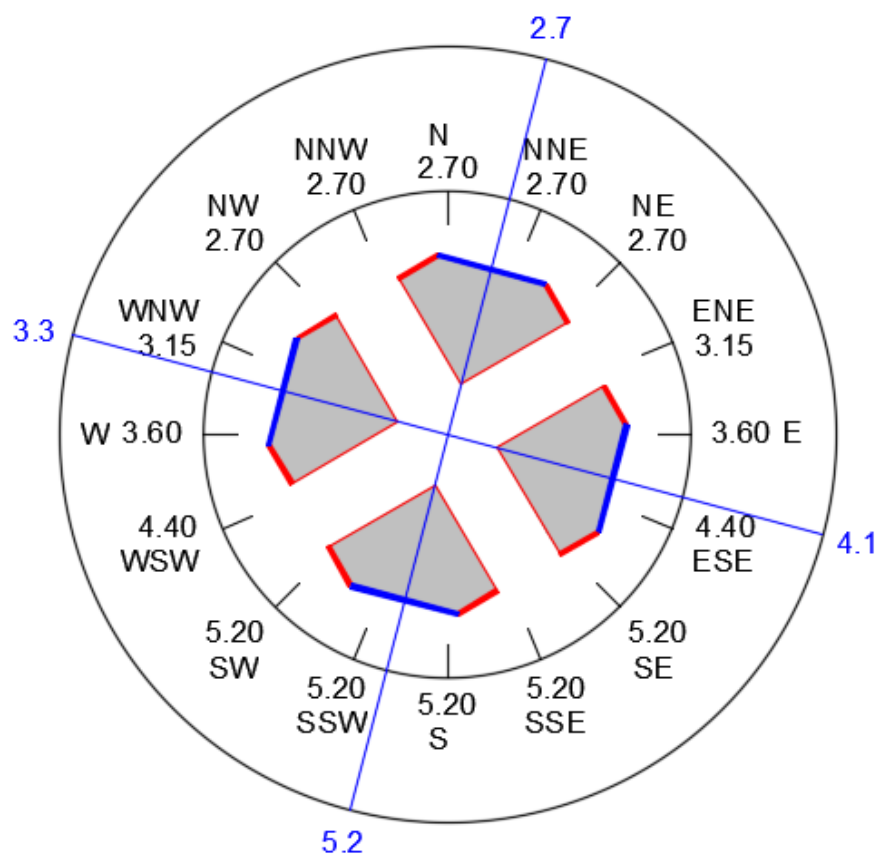

Orientation of each building into the urban blocks and recommended limits for the $\mathrm{U}_{\text {value }}$ of openings taking into account the orientation of each facade of the urban block and openings the total area of which is equivalent to $51 \%$ to $60 \%$ of the total wall area

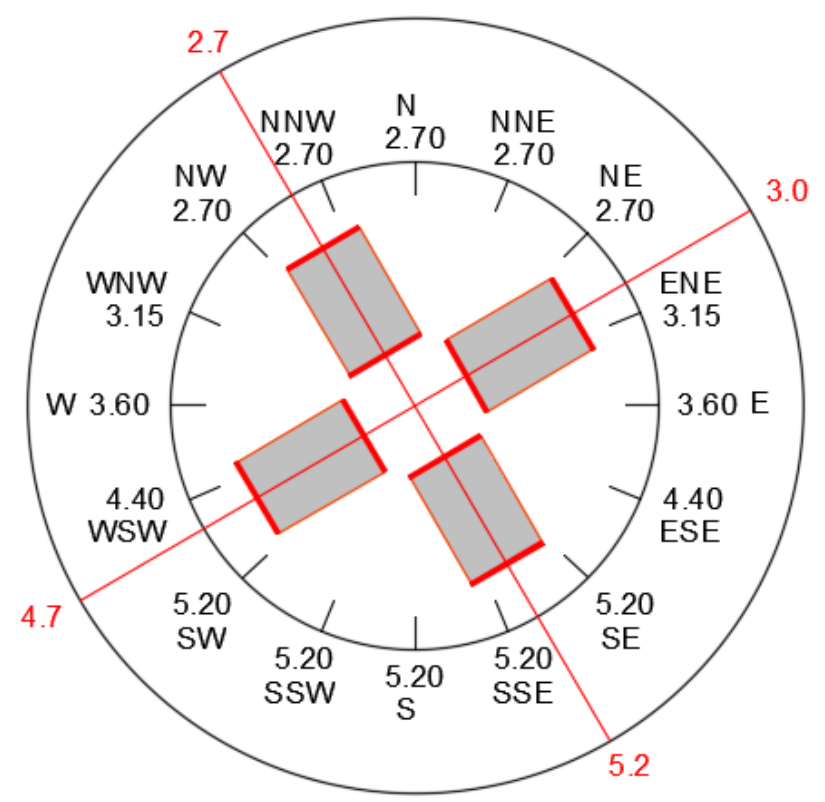

Weighted mean of the recommended limit $\mathrm{U}_{\text {value }}$ for openings $3.88 \mathrm{~W} / \mathrm{m}^{2} \mathrm{~K}$

(this value takes into consideration the length and orientation of all facades in the urban block)

Other recommended limits for $U_{\text {values }}$

External walls

Roofs

Party walls

Partitions (same use)
Floors

$0.82 \mathrm{~W} / \mathrm{m}^{2} \mathrm{~K}$ $0.52 \mathrm{~W} / \mathrm{m}^{2} \mathrm{~K}$ $0.45 \mathrm{~W} / \mathrm{m}^{2} \mathrm{~K}$ $1.10 \mathrm{~W} / \mathrm{m}^{2} \mathrm{~K}$
Fig. 11 Maximum recommended transmittances for each facade orientation. Spanish climate zone B (Ministerio de Fomento. Gobierno de España, 2013) 


\subsection{Compared analysis of construction characteristics}

252 To compare these values to the current transmittances of the envelope of the abovementioned

253 listed building stock, the authors have inspected a randomly chosen sample of 20 listed build-

254 ings (type B or C) located in l'Eixample. The access to each dwelling was granted by the private owners or by estate agencies that offered these flats either for renting or for sale. This review confirms that the envelopes of these residences (external walls, openings and roofs) currently remain as-built and apparently have a substantial lack of thermal insulation. Furthermore, this examination also endorses the information presented in earlier and more extensive studies (Fran Bretones, 1990) regarding the construction techniques used to build most of the listed buildings type B or C during the period from 1887 until 1940.

Taking into account the available information, the current transmittance of each element of the envelope has been calculated and these results have been compared to the limit $U_{\text {values }}$ (compulsory and recommended) prescribed in the CTE-HE code. The results for each part of the building are discussed and conclusions about the energy saving potential and the foreseeable reduction of $\mathrm{CO}_{2}$ emissions are presented.

\subsection{External walls}

Usually, the vertical structure of these multi-storey buildings was designed using brickwork elements. Therefore, facades, party walls and staircases are load-bearing walls. Inner masonry columns often complete the vertical structural system.

The load-bearing facades (facing the street and the backyard) were constructed with one leaf of solid ceramic fired bricks and lime mortar. The walls were coated with mortar plaster outdoors and gypsum plaster indoors. The thickness of these walls varies from $52 \mathrm{~cm}$ to $40 \mathrm{~cm}$ while their thermal resistance ranges from $0.83 \mathrm{~m}^{2} \cdot \mathrm{K} / \mathrm{W}$ to $0.65 \mathrm{~m}^{2} \cdot \mathrm{K} / \mathrm{W}$ (Fig. 12a). Hence, the transmittance of these walls varies from 1.02 to $1.23 \mathrm{~W} / \mathrm{m}^{2} \mathrm{~K}$.

Similar compositions were used for the party walls, the staircase walls and the facades of the small ventilation patios. In these cases the thickness of the wall is $12 \mathrm{~cm}$ and the thermal re- 
sistance decreases to $0.23 \mathrm{~m}^{2} \cdot \mathrm{K} / \mathrm{W}$ (Fig. 12b). Hence, the transmittance of the party walls and the staircase walls is $2.06 \mathrm{~W} / \mathrm{m}^{2} \mathrm{~K}$ while the transmittance of the walls of the small ventilation patios increases up to $2.52 \mathrm{~W} / \mathrm{m}^{2} \mathrm{~K}$.

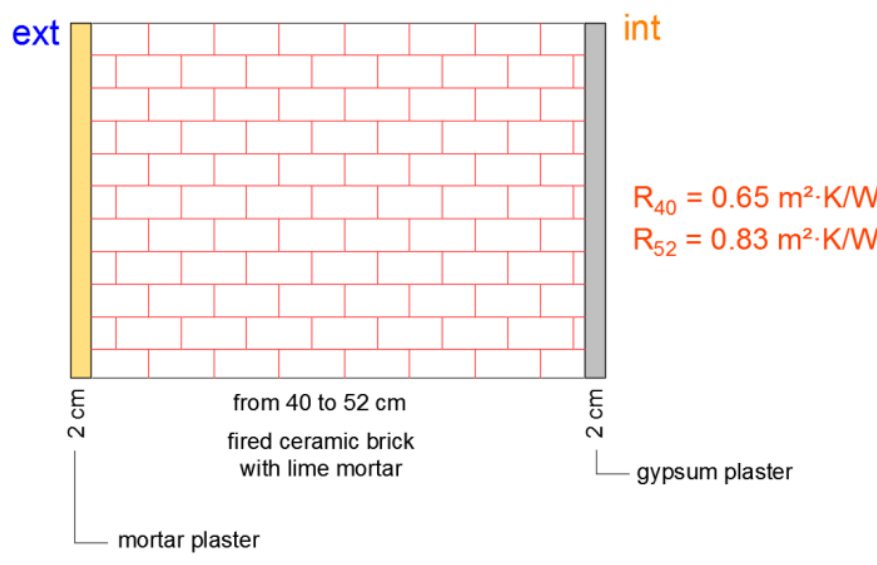

a. Street/backyard facade bearing wall

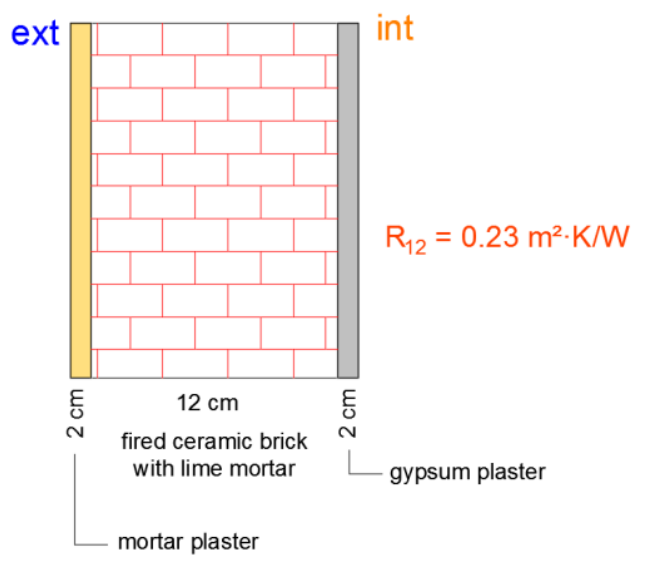

b. Patio facade and party walls

Fig. 12 Wall composition and thermal resistance of masonry walls

As a result, the $U_{\text {value }}$ of all external walls substantially exceeds the recommended transmittance. The surplus of transmittance ranges from $38 \%$ to $207 \%$ (Table 3 ). Party walls and the staircase walls also exceed the recommended values. In this case the surplus is $87 \%$ and $72 \%$ respectively (Table 3). Given this significant lack of insulation and the large number of dwellings in this situation, the retrofitting of this part of the envelope has a significant energy-saving potential.

The protection grade of these listed buildings does not allow any street facade changes. However, ventilation patios, backyard facades, party walls and staircases walls could be efficiently retrofitted in order to substantially reduce their transmittance.

\subsection{Openings}

The composition of the street facade openings is mainly based on balconies and medium size windows and doors (Fig. 13). All these openings were made of two or three sheets of painted wood with single glass framing deployed only in the upper part of the opening. These pieces of 

openings in the analysed sample fluctuates from $40 \%$ to $70 \%$ with an average of $58 \%$. Accordingly, the theoretical $U_{\text {value }}$ of these openings ranges from 3.60 to $4.65 \mathrm{~W} / \mathrm{m}^{2} \mathrm{~K}$. In the street facade, the average area of openings ranges from $39 \%$ to $53 \%$ of the total facade area.
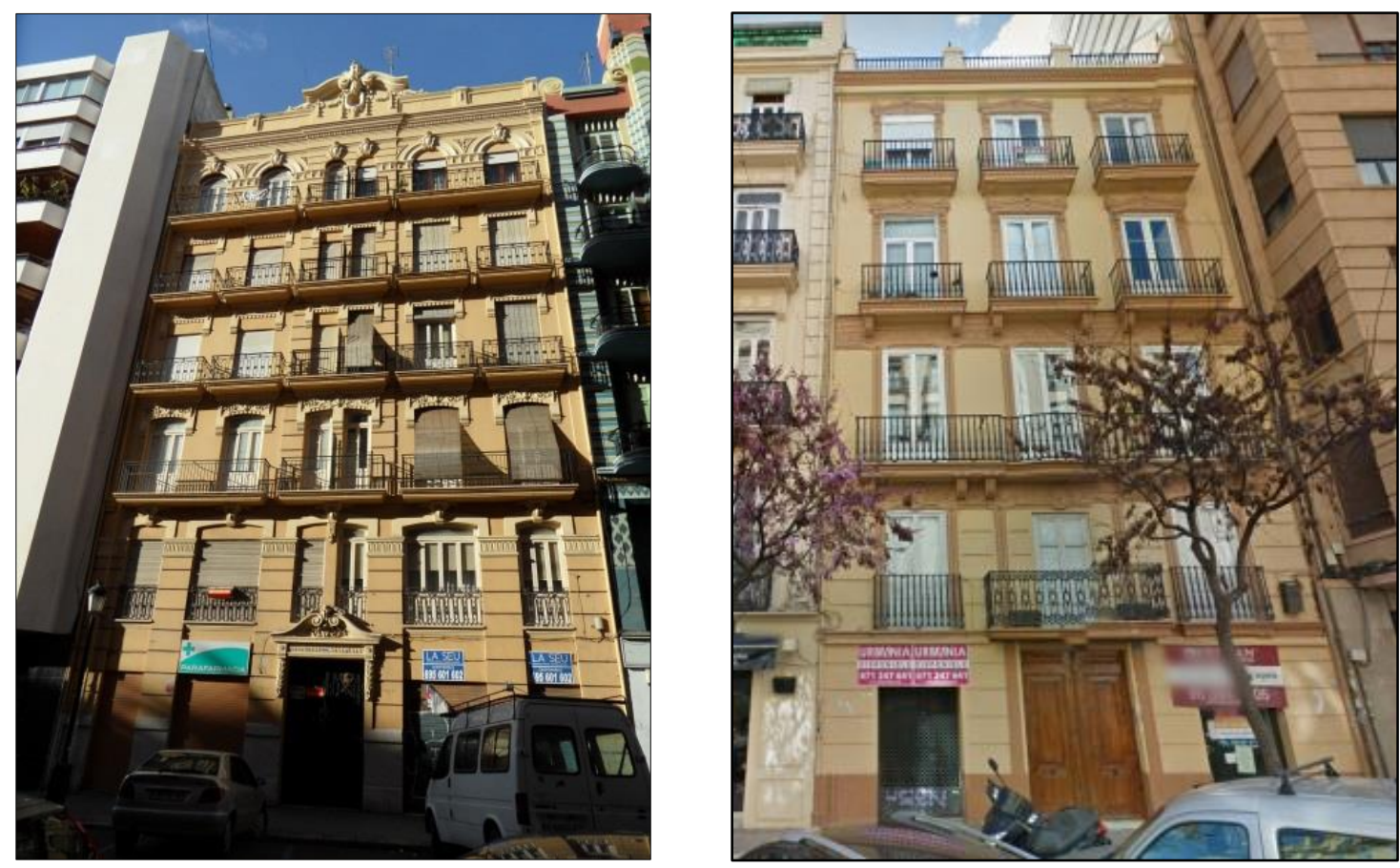

Fig. 13 Usual street facades in l'Eixample of Valencia

The weighted mean limit $\bigcup_{\text {value }}$ has been calculated taking into account the total facade area of each urban block and the orientation of the longest facades (azimuth $60^{\circ}$ ). The resulting limit transmittance is $3.88 \mathrm{~W} / \mathrm{m}^{2} \mathrm{~K}$ (Fig. 11). Hence, according to the currently recommended limit $\bigcup_{\text {value }}$ for the climate zone $\mathrm{B}$ and for opening ratios from $51 \%$ to $60 \%$ (Fig. 10 and Fig. 11), only those openings with glazing surface ratios smaller than $46 \%$ (one out of four of the current openings) would have acceptable transmittances. Nevertheless, the energy-saving potential

312 associated to the improvement of the thermal efficiency of these elements is smaller than $20 \%$

313 (Table 3) and the refurbishing restrictions imposed to these listed buildings prevent any altera-

314 tion of these carpentry elements. 
The excessive sun radiation was prevented by means of either internal or external timber shutters or traditional blinds (Fig. 14). Balconies were built using stone slabs $7 \mathrm{~cm}$ thick embedded into the wall facade and overhanging from 50 to $65 \mathrm{~cm}$ (Fig. 14). The shade projected by these cantilevers, the considerable thickness of the facade walls and the location of the carpentry (aligned to the inner face of the walls), moderates the overheating produced by sunlight, especially in summertime (Fig. 13, Fig. 14). Hence, no significant improvement could be obtained from additional sun radiation control.
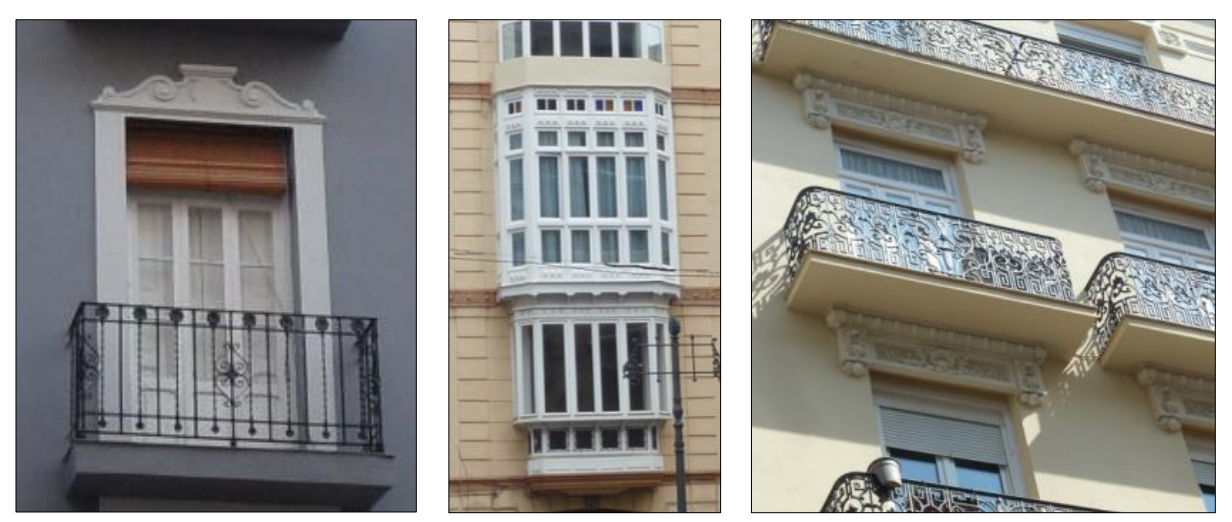

Fig. 14 Openings details and sunlight protection devices

The backyard facade was considered a secondary part of the building and was not designed as carefully as the front facade was. In this case the average area of openings varies from $21 \%$ to $32 \%$ of the total facade area, there are usually less openings but windows are larger and scarcely protected from sunlight radiation (Fig. 15). The glazing surface ratio of these openings varies from $60 \%$ to $80 \%$ with an average of $68 \%$. The theoretical $\bigcup_{\text {value }}$ of these openings will range from 4.30 to $5.00 \mathrm{~W} / \mathrm{m}^{2} \mathrm{~K}$. Therefore, attending to the currently recommended limit transmittance, none of these openings have an acceptable $U_{\text {value. }}$ In this case, the openings have an energy-saving potential that ranges from $10 \%$ to $29 \%$ (Table 3 ) that could be achieved by means of appropriate retrofitting investments, especially because these openings are not part of the heritage protection. 

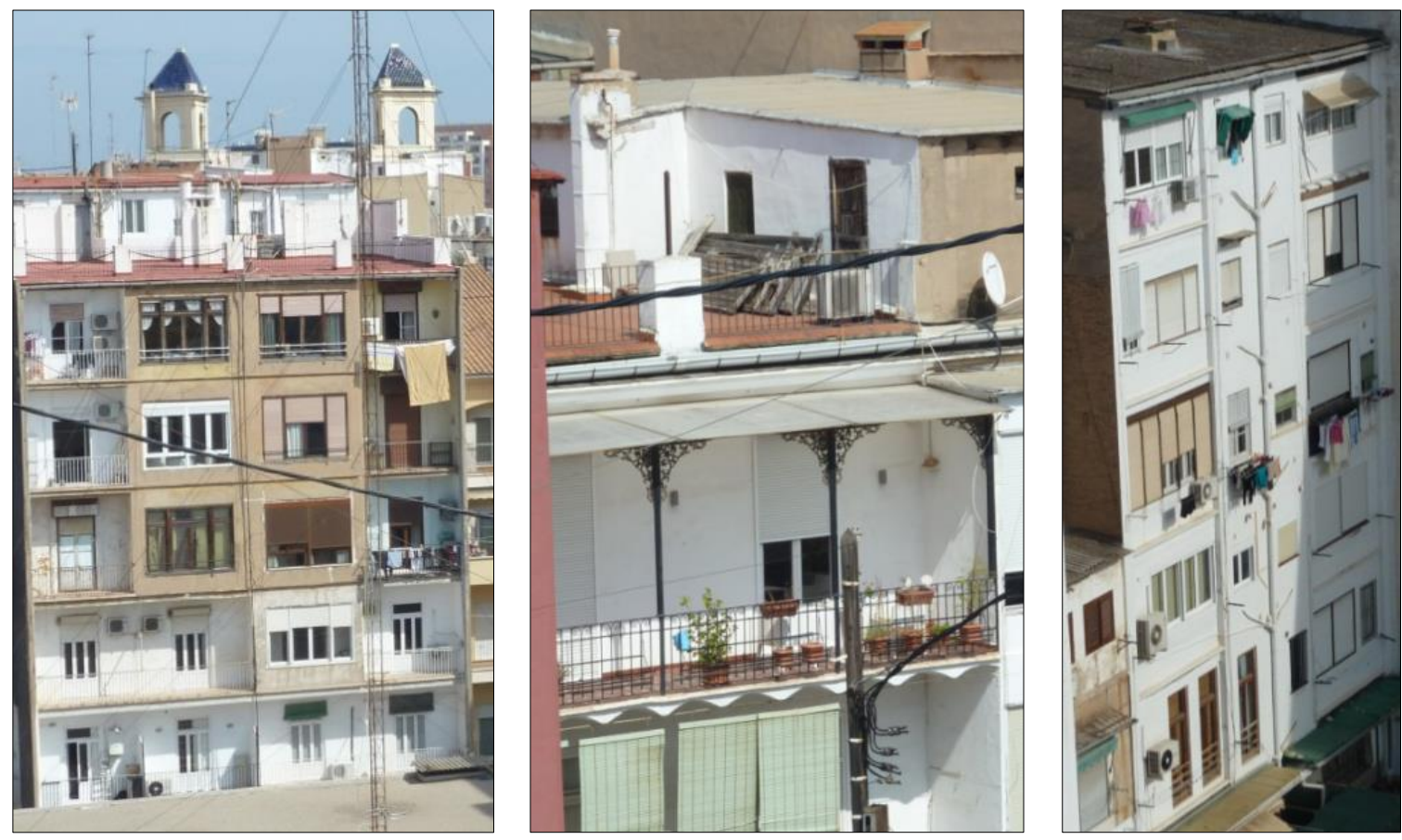

Fig. 15 Usual backyard facades, opening types and sunlight protection

338 Openings located in facades of small ventilation patios are small elements $\left(<0.3 \mathrm{~m}^{2}\right)$. Therefore, improvements in their transmittance will not influence the global thermal behaviour of the envelope of these buildings substantially.

341 In the analysed sample no blow-door tests were performed but a careful inspection of all win-

342 dows and balcony doors revealed acceptable air tightness.

\subsection{Floors and roofs}

344 Two types of floor structures were usually built from 1887 to 1940 . Initially, the floors were con-

345 structed using beams and joists made of timber (Fig. 16a), later these structural elements were

346 built using rolled steel (Fig. 16b). In both cases joists were coupled with lightweight masonry

347 vaults. Suspended ceilings, made of reed and gypsum, conceal the structure of these roofs. 


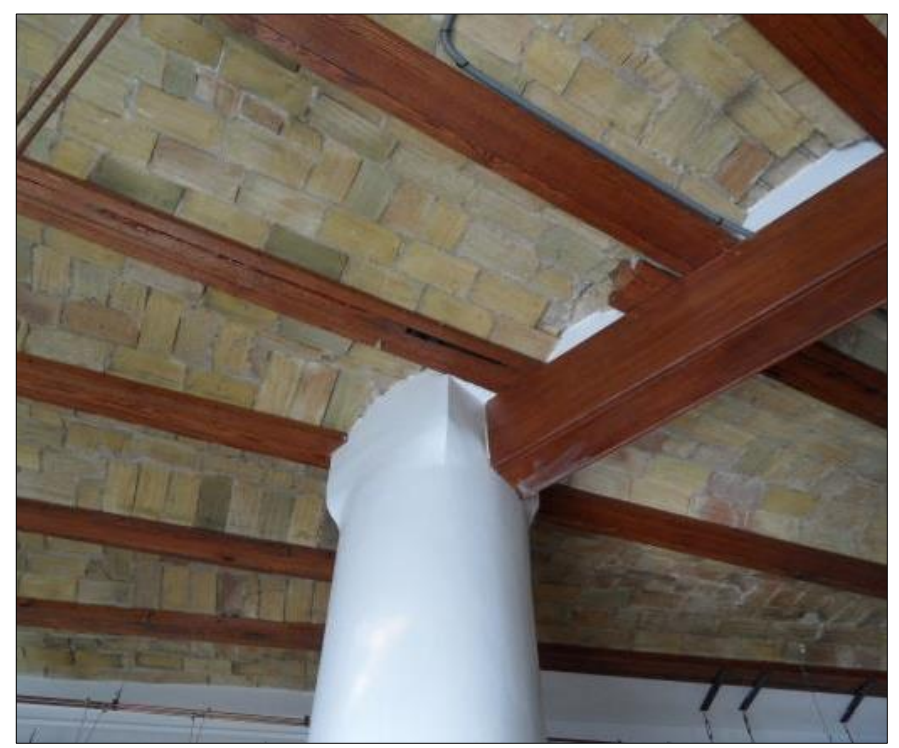

a. Timber joists and beams

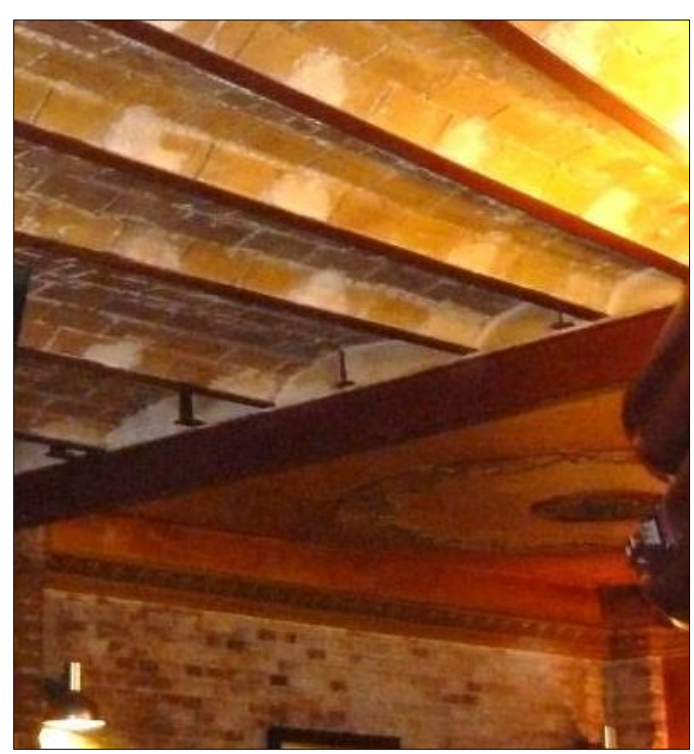

b. Rolled steel joist and beams

Fig. 16 Types of structure used for floors

353 Buildings constructed with a timber structure have gable roofs the slope of which is usually $35433 \%$. Traditional ceramic curved tiles are placed over a board of ceramic flat bricks and gypsum 355 plaster that is supported by timber purlins and rafters (Fig. 17 and Fig. 18). The space between 356 the roof and the suspended ceiling slightly reduces the significant lack of thermal insulation of 357 dwellings placed on the top storey of the building. The $U_{\text {value }}$ of this type of roof is extremely 358 high $\left(1.96 \mathrm{~W} / \mathrm{m}^{2} \mathrm{~K}\right)$ compared to the currently recommended limit value of $0.45 \mathrm{~W} / \mathrm{m}^{2} \mathrm{~K}$ (Fig. 11). 


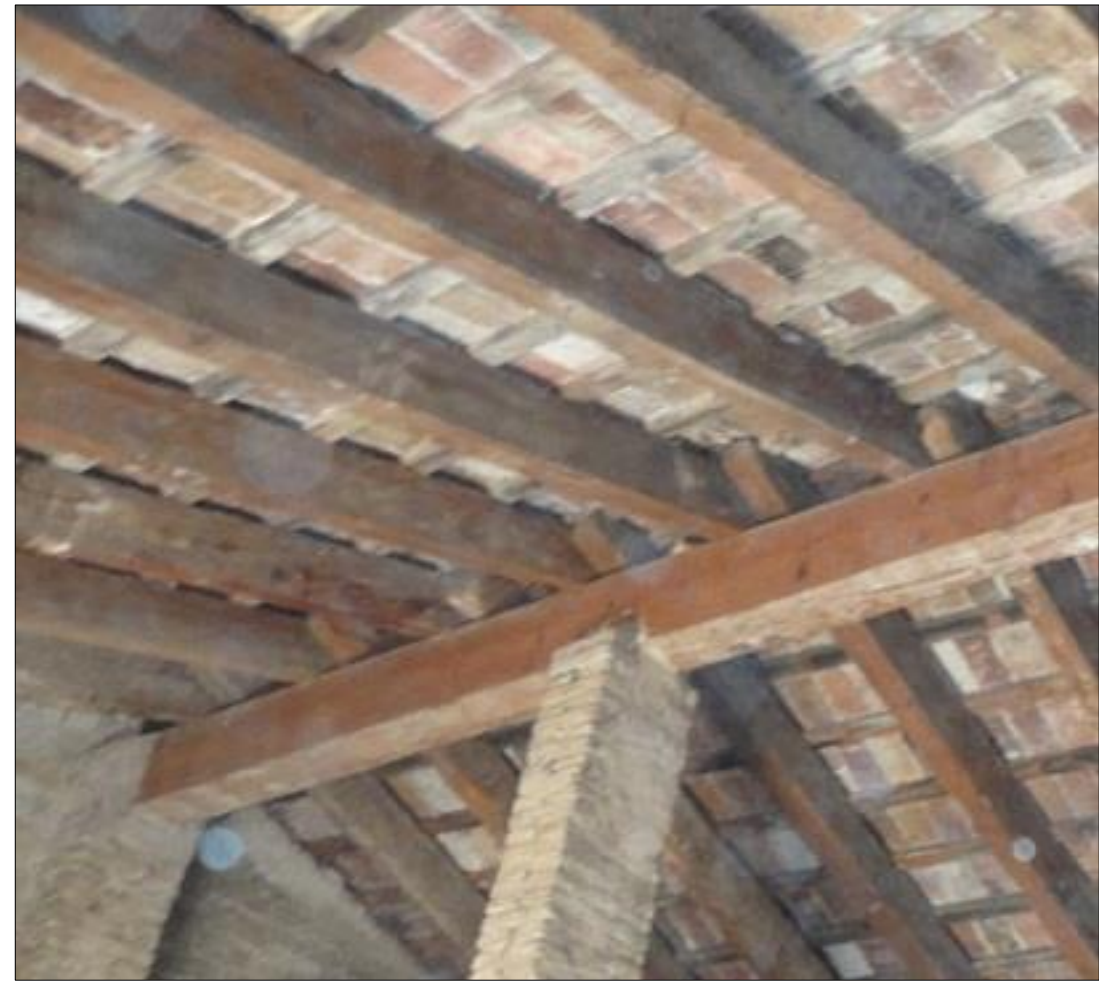

Fig. 17 Gable roof design for buildings with timber structure

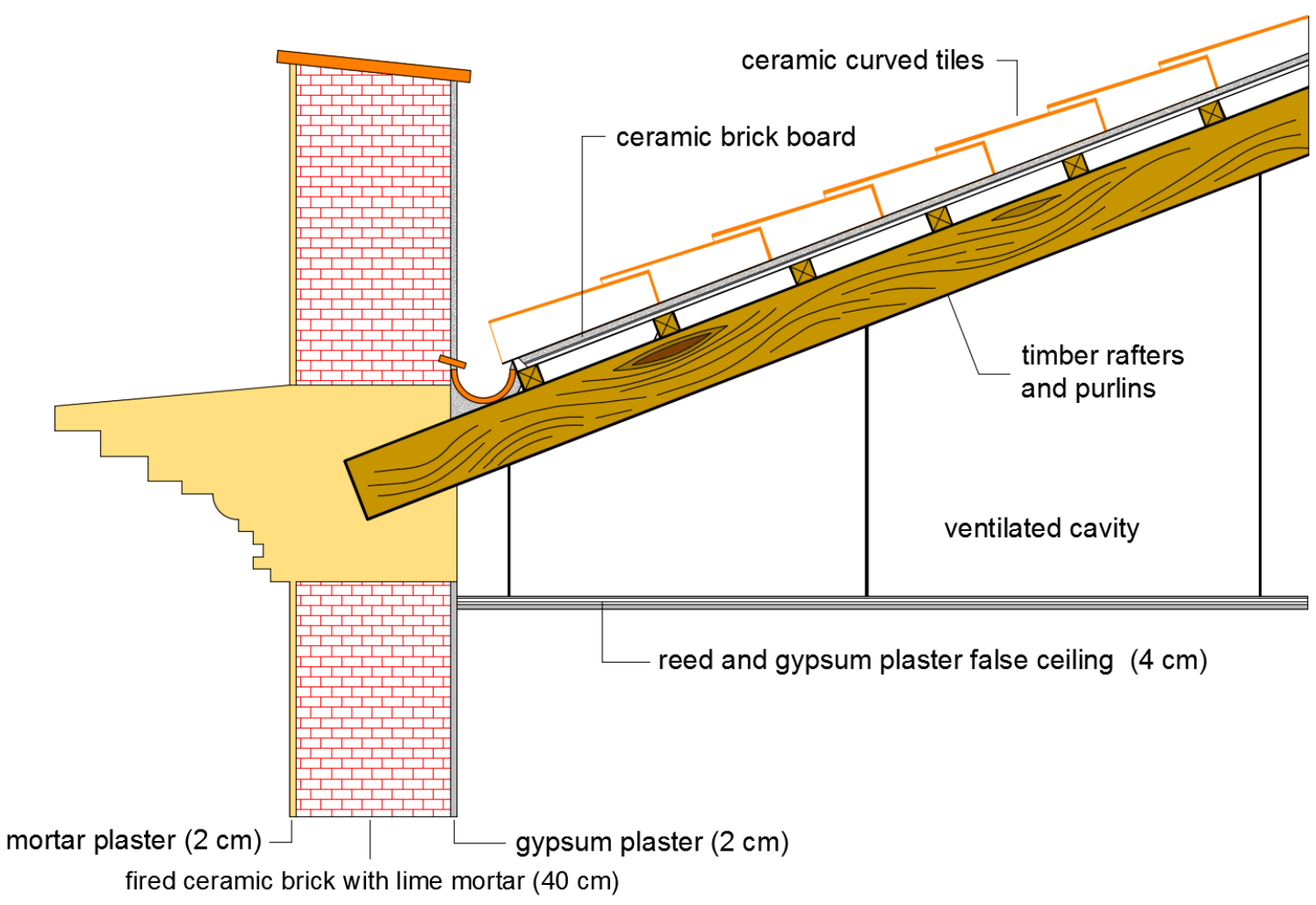

Fig. 18 Gable roof details for buildings with timber structure 
367 In later times, when rolled steel was used for the structure of the building, the roofing evolved

368 and the first bay was transformed into a flat roof, providing space for clotheslines, while roof

369 level private store-rooms were built under the gable (Fig. 19 and Fig. 20). The $\bigcup_{\text {value }}$ of this roof

370 type of is $1.35 \mathrm{~W} / \mathrm{m}^{2} \mathrm{~K}$. This design improves the performance of the former design but is still

371 well above the recommended limit value. fired ceramic brick with lime mortar $(40 \mathrm{~cm})$

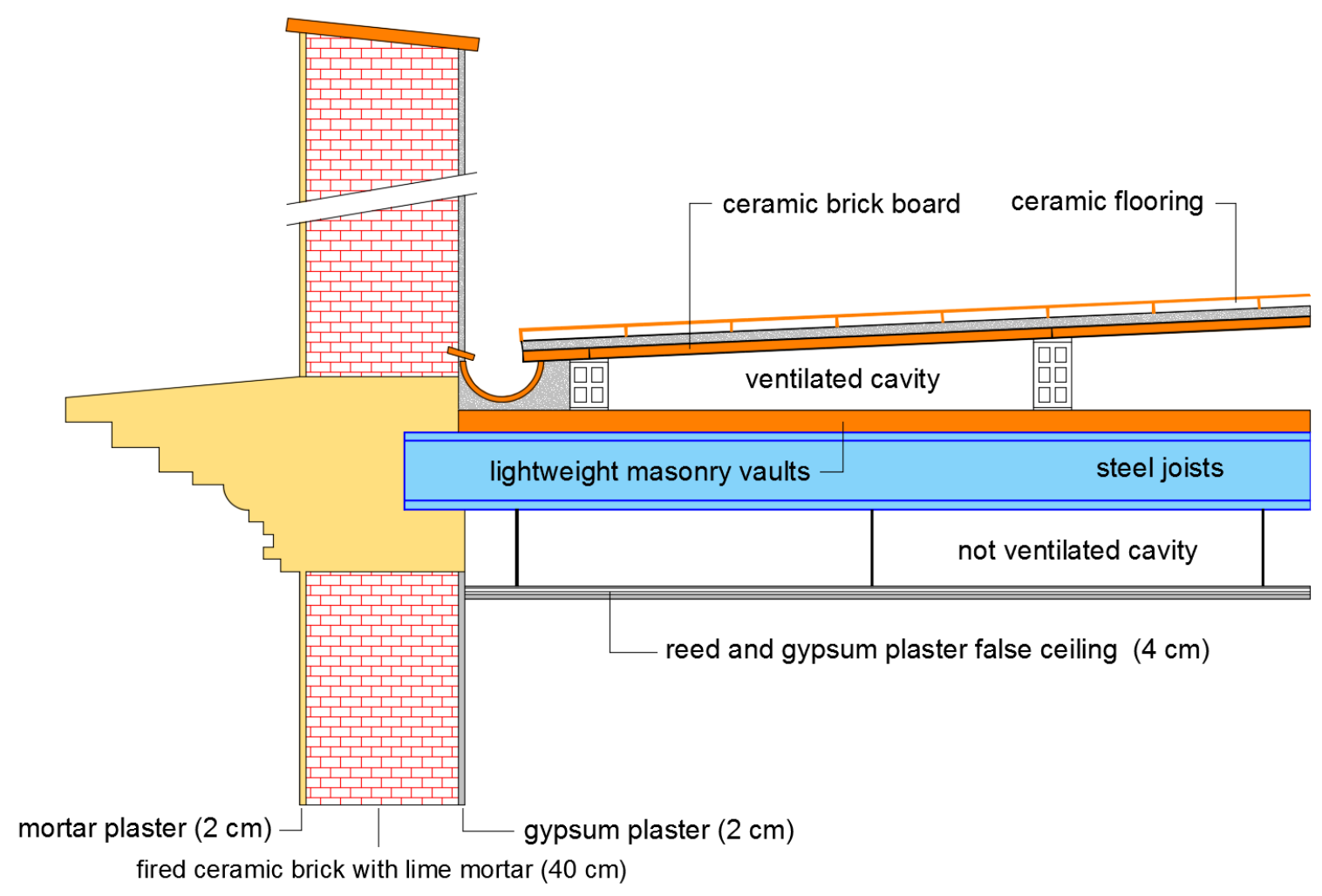

Fig. 19 Roof design for buildings with structure of rolled steel beams and joists 


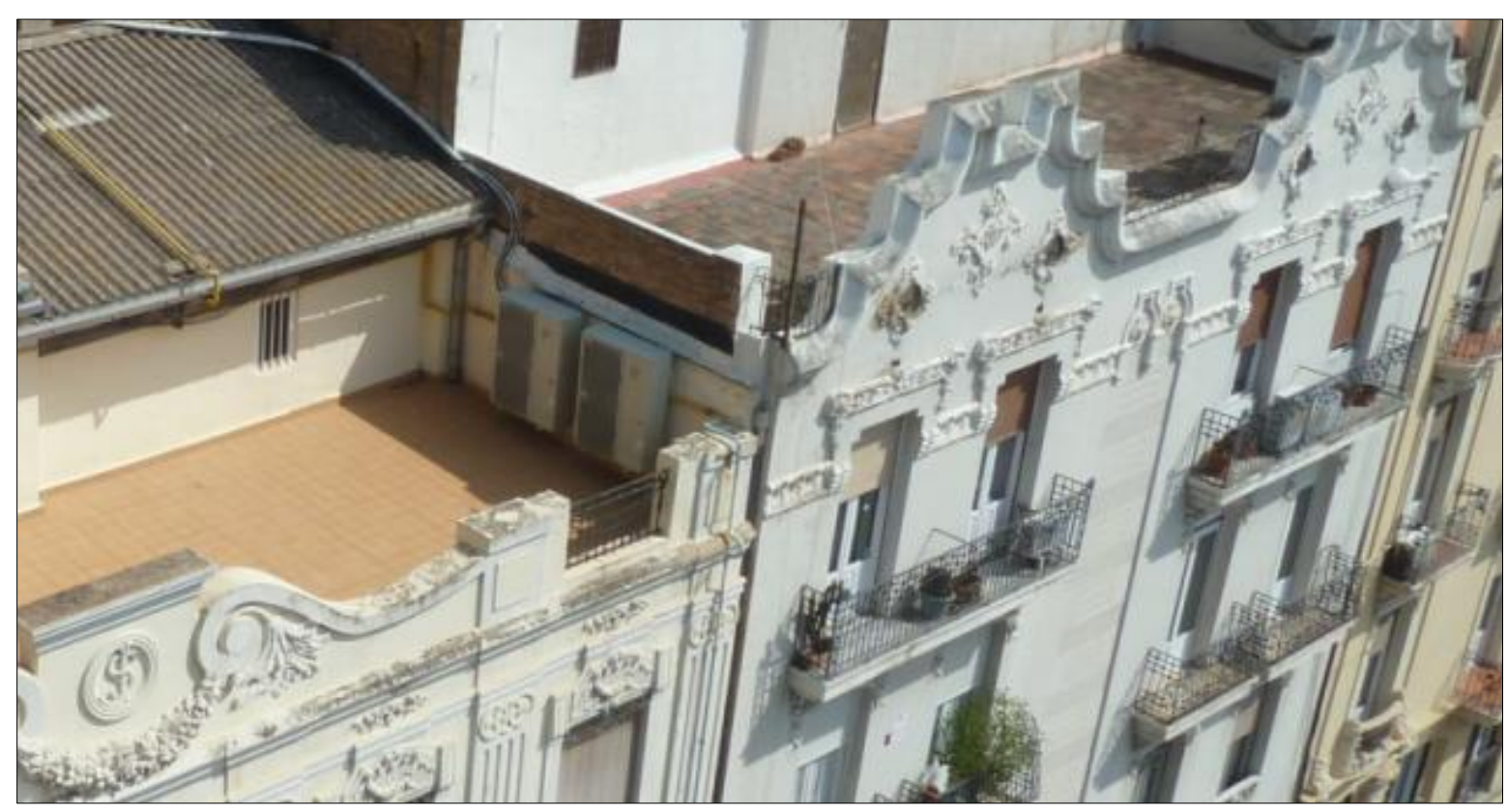

Fig. 20 Roofing evolution of the first bay providing space for clotheslines

Since 1940, rigid frames of reinforced concrete combined with one-way floor slabs have been the most usual type of structure in this area. However, these more recently constructed buildings are not included in this study because of their lack of homogeneity.

The excess of transmittance of these roofs ranges from $200 \%$ to $336 \%$ (Table 3 ). The energysaving potential of this part of the envelope is certainly substantial for the building as a whole, but given that $85 \%$ of the total area of the envelope of flats located on the top storey corresponds to the roof, the abovementioned lack of thermal insulation reduces drastically the level of comfort of these dwellings. Fortunately, the roofs are not submitted to heritage protection restrictions. As a result, retrofitting works intended to improve the thermal insulation of these roofs will not only improve the comfort and sustainability but also will be cost-efficient because of the short payback period.

\subsection{Summary of results and energy-saving potential of the building envelope}

The theoretical thermal efficiency of each part of the envelope of the most characteristic listed buildings located in l'Eixample of Valencia has been detailed and summarised in Table 3 . This 
table also shows the recommended transmittances, and the potential improvement of each part

394 has been highlighted.

395 These results show that the most relevant retrofitting measures concerning the envelope of 396 these buildings are concentrated on roofs and walls of ventilation patios facades. Party walls 397 and staircases walls should also significantly improve their thermal efficiency.

398

399

400

401

402

403

404

\begin{tabular}{|c|c|c|c|c|c|c|c|c|c|c|}
\hline \multirow[b]{3}{*}{$\begin{array}{l}\text { Transmittances } \\
{\left[\mathrm{W} / \mathrm{m}^{2} \mathrm{~K}\right]}\end{array}$} & \multirow{2}{*}{\multicolumn{2}{|c|}{ Roofs }} & \multicolumn{6}{|c|}{ External walls } & \multicolumn{2}{|c|}{ Internal walls } \\
\hline & & & \multicolumn{2}{|c|}{ Street facade $(27 \%)$} & \multicolumn{2}{|c|}{ Backyard facade (27\%) } & \multicolumn{2}{|c|}{ Vent patios facades (46\%) } & \multirow{2}{*}{$\begin{array}{l}\text { Party } \\
\text { walls }\end{array}$} & \multirow{2}{*}{$\begin{array}{c}\text { Staircase } \\
\text { walls }\end{array}$} \\
\hline & $\begin{array}{c}\text { Timber } \\
\text { structure }\end{array}$ & \begin{tabular}{|c} 
Steel \\
structure
\end{tabular} & $\begin{array}{l}\text { Wall } \\
(21 \%) \\
\end{array}$ & $\begin{array}{c}\text { Openings } \\
(6 \%)\end{array}$ & $\begin{array}{l}\text { Wall } \\
(17 \%) \\
\end{array}$ & \begin{tabular}{|c}
$\begin{array}{c}\text { Openings } \\
(10 \%)\end{array}$ \\
\end{tabular} & $\begin{array}{l}\text { Wall } \\
(42 \%) \\
\end{array}$ & $\begin{array}{c}\text { Openings } \\
(4 \%)\end{array}$ & & \\
\hline Maximum allowed & 0.65 & 0.65 & 1.00 & 4.20 & 1.00 & 4.20 & 1.00 & 4.20 & 1.10 & 1.20 \\
\hline Recommended limit & 0.45 & 0.45 & 0.82 & 3.88 & 0.82 & 3.88 & 0.82 & 3.88 & 1.10 & 1.20 \\
\hline Currently (as-built) & 1.96 & 1.35 & 1.13 & 4.65 & 1.13 & 5.00 & 2.52 & 5.00 & 2.06 & 2.06 \\
\hline \begin{tabular}{|l} 
Recommendable \\
increment of \\
insulation
\end{tabular} & $336 \%$ & $200 \%$ & $38 \%$ & $20 \%$ & $38 \%$ & $29 \%$ & $207 \%$ & $29 \%$ & $87 \%$ & $72 \%$ \\
\hline
\end{tabular}

Table 3 Summary of the current thermal behaviour of building's envelope and ranges of improvement

\section{Space heating/cooling systems and domestic hot water production}

An extensive survey was also conducted to identify and classify the technical systems that provide thermal comfort in most of these listed buildings.

Regarding the space heating of these dwellings, the most frequent system is based on electric heaters $(35 \%)$ or electric heat pumps $(30 \%)$. However, in some cases, boilers using natural gas (25\%), individual burners of butane gas supplied in gas cylinders $(5 \%)$ or other systems $(5 \%)$ are also used. Despite the high eco-efficiency of natural-gas-engine-driven heat pumps (Brenn, Soltic, \& Bach, 2009) and the better performance of these systems compared to electrically driven heat pumps or more conventional heating systems (Brenn, Soltic, \& Bach, 2010), this type of technical system is not present in these buildings.

During the hot season, most of the existing electric heat pumps run in reverse mode and provide space cooling. Nevertheless, opening awnings, closing blinds and curtains, and allowing 
414 night-time cross ventilation are the most frequent practices to prevent the overheating of these

415 dwellings.

416 Concerning the domestic hot water production, there are three systems that are used in the 417 same proportion: individual electric boilers, individual burners of butane gas and individual boil418 ers burning natural gas (also used as space heating systems). Despite the high rate of solar 419 radiation of this geographic area, there are no thermal solar systems installed in this residential 420 stock.

\section{Energy efficiency and retrofitting measures}

The energy efficiency of these buildings could be improved by reducing the transmittance of the envelope and by decreasing the high dependency on electric energy to supply domestic hot water and for space heating purposes.

Regarding the insulation of walls, it should be taken into account that locating the insulation at the external side of the facade is more efficient. However, expensive scaffolding systems and appropriate solutions to protect the insulation are required. Additionally, the protection requirements of this architectural heritage prevent any modification of the street facade. Therefore, the positioning of the insulation from the interior is more convenient in economic terms and it is the only option compatible with the safeguard of the architectural heritage value of these buildings. Usually, the internal location of the insulation increases the water vapour condensation potential but it has been found (Kolaitis et al., 2013) that a minor condensation risk can be expected for this solution because of the mild Mediterranean climate conditions of this region.

The high transmittance of the roof in the top floor residences increases the energy demand (compared to those located in lower floors) not only during the winter season but also during the summer season. The absence of cast shadows increases the heat gains from solar radiation. These benefits along the winter season do not completely compensate the heat losses due to such poorly insulated roof. For the same reasons, during the summer season, substantial heat 
gains - due to high air temperatures and solar radiation - take place in these dwellings. There-

440 fore, top floor residences usually have an energy saving potential much larger than those locat-

441 ed in lower floors. As a consequence, major retrofitting works should be undertaken to substan-

442 tially reduce the transmittance of the roof.

443 Concerning the openings of the building's envelope, the state of preservation and appropriate-

444 ness (in terms of size, shape, frame materials and glazing system) has been checked. This ap-

445 praisal has shown that the current configuration of openings and shading devices properly pre-

446 vents the heat losses caused by the thermal flux and the excessive heat gains from solar radia-

447 tion. Therefore, the potential sustainability benefits to be obtained from this intervention are not

448 relevant.

449 All buildings in the area of study have access to natural gas supply. Therefore, a progressive 450 transition to more efficient systems like natural-gas-engine-driven heat pumps is possible. Do451 mestic hot water for all dwellings in each building could be perfectly provided by means of ther452 mal solar systems located on the building's roof or along the large backyards of these buildings. 453 The cost-efficiency of both retrofitting measures should be precisely quantified but that analysis 454 is out of the scope of this paper.

\section{Conclusions}

456 A homogenous stock of 600 multi-storey listed buildings (circa 5.000 dwellings) located in l'Eixample of Valencia (Spain) has been statistically analyzed in terms of the thermal performance of the envelope and eco-efficiency of space heating/cooling and the domestic hot water production systems. The findings show a substantial lack of thermal insulation. Furthermore, most of the surveyed space heating/cooling systems and the domestic hot water production systems are obsolete or inefficient in terms of energy consumption and also in terms of use of renewable sources of energy. 
This paper shows that the envelope of most of these dwellings remains as-built at the beginning of the past century. The appraisal of the thermal behaviour of these buildings proves that their transmittance is substantially higher than the limits fixed by the current Spanish building code CTE-HE. At the same time, the eco-efficiency of the technical systems remains far from the current acceptable standards. The main reasons for this situation are:

- Architectural heritage is exempt from the current energy regulations that are generally enforced on buildings.

- Not all types of retrofitting measures can be applied to listed buildings since some parts of the building are protected and must remain untouched.

- From the point of view of the owners, the mild climate of this Mediterranean region does not apparently require investments to improve the thermal comfort increasing the thermal efficiency of the envelope of the building or the eco-efficiency of the technical systems.

- Investments in thermal retrofitting have not been cost-efficient for many years because of the relative low economic cost of the energy.

However, given the large amount of buildings included in this housing stock, the energy-saving potential is substantial and authorities should pay attention to the resultant social benefits and propose alternative approaches to improve the sustainability of listed buildings.

Some feasible retrofitting measures, that take into account not only the listed nature of these buildings but also the mild climate of this Mediterranean region, are proposed. The following list 482 has been sorted attending to the energy-saving potential revealed in this study by each retrofitting measure:

1. Reduction of the transmittance of roofs. This measure will bring/provide the most important reduction of heat flux through the envelope. This measure has a long payback period but the comfort improvement of residences in upper floor will be substantial. Moreover, the investment should be supported by all dwellings in the building. 

ventilation patios. In all cases, high efficiency insulation panels could be located in the inner side of these walls. This solution will prevent any alteration of protected facades and does not need scaffolding. In order to improve the behaviour of the envelope during the long summer season it would also be advisable to increase the thermal mass of these walls.

3. Upgrade of the technical systems providing space heating/cooling and domestic hot water production. Migration from electrically powered systems to natural-gas-engine-driven heat pumps is highly advisable considering the current supply availability, the advisable levels of comfort and the geographical location. nal insulation of walls.

Alev, Ü., Eskola, L., Arumägi, E., Jokisalo, J., Donarelli, A., Siren, K., ... Kalamees, T. (2014). Renovation alternatives to improve energy performance of historic rural houses in the Baltic Sea region. Energy and Buildings, 77, 58-66. http://doi.org/10.1016/j.enbuild.2014.03.049

Alonso, L., \& Almazán, G. (2012). Compatibilidades entre revitalización y protección en la edificación del Ensanche de Valencia: la "transformabilidad" de las edificaciones. Arché. IRP. Universitat Politècnica de València, (7), 95-102.

Balaras, C. a., Gaglia, A. G., Georgopoulou, E., Mirasgedis, S. Sarafidis, Y., \& Lalas, D. P. (2007). European residential buildings and empirical assessment of the Hellenic building stock, energy consumption, emissions and potential energy savings. Building and $\begin{array}{lr}\text { Environment, } & \text { 42(3), 1298-1314. }\end{array}$ http://doi.org/10.1016/j.buildenv.2005.11.001

Brenn, J., Soltic, P., \& Bach, C. (2009). An Approach For Efficiency Modelling of Natural Gas Driven Heat Pumps using Standardized Test Data from Electrically Driven Heat Pumps. Supplementary Data to the Energy and Buildings Article: DOI 10.1016/j.enbuild.2009.12.012, 113.

Brenn, J., Soltic, P., \& Bach, C. (2010). Comparison of natural gas driven heat pumps and electrically driven heat pumps with conventional systems for building heating purposes. Energy and Buildings, 42(6), 904-908. http://doi.org/10.1016/j.enbuild.2009.12.012

City Council of Valencia. (n.d.). Valencia. City Districts. Retrieved February 1, 2017, from http://www.valencia.es/ayuntamiento/estadistica.nsf/0/5 F6BFFB9D69DB104C125740100386794/\$FILE/Valenci a_distritos.pdf?OpenElement\&=lang $=1$

City Council of Valencia. (2005). PEP-1. Plan Especial de Protección: Russafa Nord-Pla del Remei. Retrieved February 4, 2017, from http://www.aytovalencia.es/ayuntamiento/urbanismo.nsf/

City Council of Valencia. (2007). PEP-2. Plan Especial de Protección: Ruzafa Sur-Gran Vía. Retrieved February 4, 2017, from http://www.aytovalencia.es/ayuntamiento/urbanismo.nsf/

City Council of Valencia. (2013). Housing Census Data. Retrieved March 4, 2016, from http://www.valencia.es/ayuntamiento/estadistica.nsf/

Droutsa, K. G., Kontoyiannidis, S., Dascalaki, E. G., \& Balaras, C. A. (2016). Mapping the energy performance of hellenic residential buildings from EPC (energy performance certificate) data. Energy, 98, 284-295. http://doi.org/10.1016/j.energy.2015.12.137

European Commission. (n.d.-a). Climate Action. EU Action. Strategies. 2020 climate \& energy package. Retrieved February 13, 2016, from http://ec.europa.eu/clima/policies/strategies/2020/index_ en.htm

European Commission. (n.d.-b). Climate Action. EU Action. Strategies. 2030 climate \& energy framework. Retrieved February 13, 2016, from http://ec.europa.eu/clima/policies/strategies/2030/index_ en.htm 
Fran Bretones, J. M. (1990). Técnicas de rehabilitación. Soluciones específicas a las lesiones existentes en los inmuebles del Ensanche de Valencia de 1887. PhD Thesis. Universitat Politècnica de València. Retrieved from

http://www.cibernetia.com/tesis es/CIENCIAS TECNO LOGICAS/TECNOLOGIA_DE_LA_CONSTRUCCCION/R EHABILITACION_DE_EDIFICIOS/1\#sthash.tosW07bI.d puf

Google Maps. (n.d.). Valencia (Spain). Retrieved February 1, 2016, from https://www.google.es/maps/@39.4681229, $0.3485851,13.25 z$

International Energy Agency, Guertler, P., \& Smith, W. (2006). HIGH-RISE REFURBISHMENT The energy-efficient upgrade of multi-story residences in the European Union. IEA Information Paper, (November), 91.

Kolaitis, D. I., Malliotakis, E., Kontogeorgos, D. a., Mandilaras, I., Katsourinis, D. I., \& Founti, M. a. (2013). Comparative assessment of internal and external thermal insulation systems for energy efficient retrofitting of residential buildings. Energy and Buildings, 64, 123-131. http://doi.org/10.1016/j.enbuild.2013.04.004

Lechtenböhmer, S., \& Schüring, A. (2010). The potential for large-scale savings from insulating residential buildings in the EU. Energy Efficiency, 4(2), 257-270. http://doi.org/10.1007/s12053-010-9090-6

Liu, L., Moshfegh, B., Akander, J., \& Cehlin, M. (2014). Comprehensive investigation on energy retrofits in eleven multi-family buildings in Sweden. Energy and Buildings, 84, http://doi.org/10.1016/j.enbuild.2014.08.044

Mazzarella, L. (2014). Energy retrofit of historic and existing buildings. The legislative and regulatory point of view. Energy and Buildings. http://doi.org/10.1016/j.enbuild.2014.10.073

Ministerio de Fomento. Gobierno de España. Código Técnico de la Edificación. Documento Básico HE. Ahorro de Energía (2013). Spain. Retrieved from http://www.codigotecnico.org/cte/export/sites/default/we b/galerias/archivos/DB_HE_septiembre_2013.pdf

Ministerio de Industria Energía y Turismo. (2011). Analysis of the Energy Consumption in the Spanish Households.
IDAE. SPAHOUSEC. Retrieved from http://www.idae.es/index.php/mod.documentos/mem.de scarga?file=/documentos_Informe_SPAHOUSEC_ACC f68291a3.pdf

Monzón, M., \& López-Mesa, B. (2018). Buildings performance indicators to prioritise multi-family housing renovations. Sustainable Cities and Society, 38(November 2017), 109-122. http://doi.org/10.1016/j.scs.2017.12.024

Morelli, M., Rønby, L., Mikkelsen, S. E., Minzari, M. G., Kildemoes, T., \& Tommerup, H. M. (2012). Energy retrofitting of a typical old Danish multi-family building to a "nearly-zero" energy building based on experiences from a test apartment. Energy and Buildings, 54(2012), 395-406. http://doi.org/10.1016/j.enbuild.2012.07.046

Nemry, F., Uihlein, A., Colodel, C. M., Wetzel, C., Braune, A., Wittstock, B., ... Frech, Y. (2010). Options to reduce the environmental impacts of residential buildings in the European Union-Potential and costs. Energy and $\begin{array}{ll}\text { Buildings, } & 42(7),\end{array}$ http://doi.org/10.1016/j.enbuild.2010.01.009

Nemry, F., Uihlein, A., Colodel, C. M., Wittstock, B., Braune, A., Wetzel, C., ... Frech, Y. (2008). Environmental Improvement Potentials of Residential Buildings (IMPRO-Building). IPTS-JRC, European Comission. http://doi.org/10.2791/38942

Soria y Puig, A. (1995). Ildefonso Cerdá's General Theory of "Urbanización." The Town Planning Review, 66(1), 1539. Retrieved from http://www.jstor.org/stable/40113676

Tommerup, H., \& Svendsen, S. (2006). Energy savings in Danish residential building stock. Energy and Buildings, 38(6)

http://doi.org/10.1016/j.enbuild.2005.08.017

WWF. (2010). Potencial de ahorro energético y de reducción de emisiones de $\mathrm{CO} 2$ del parque Residencial existente en España - INFORME, 20. Retrieved from www.wwf.es 